\title{
Evaluation of Well Logs for Determining the Presence of Freshwater, Saltwater, and Gas above the Marcellus Shale in Chemung, Tioga, and Broome Counties, New York
}

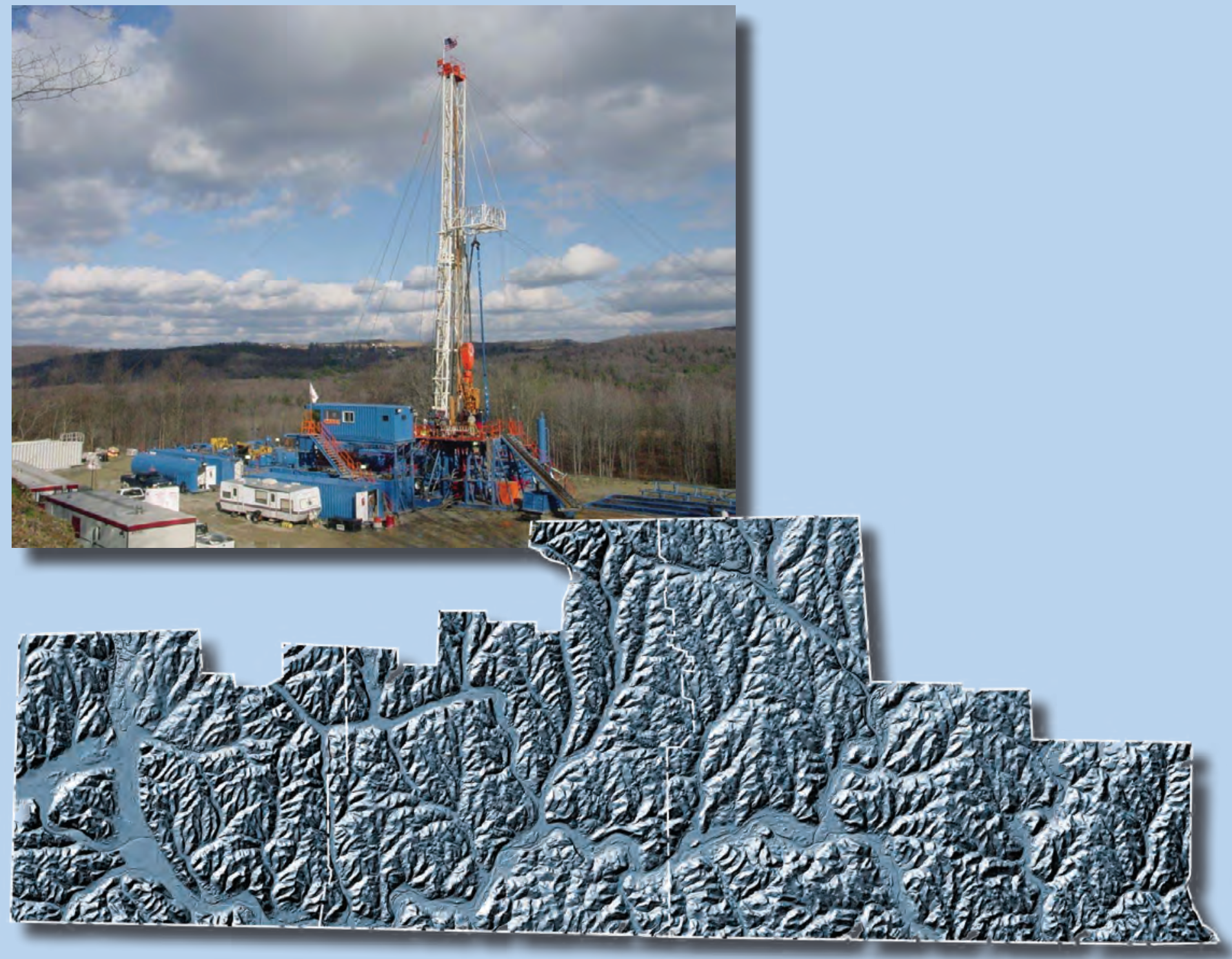

Scientific Investigations Report 2010-5224 
Cover. Gas-well drilling rig, Broome County, New York. Photograph by New York State Department of Environmental Conservation, 2005. 


\section{Evaluation of Well Logs for Determining the Presence of Freshwater, Saltwater, and Gas above the Marcellus Shale in Chemung, Tioga, and Broome Counties, New York}

By John H. Williams

Scientific Investigations Report 2010-5224 


\section{U.S. Department of the Interior \\ KEN SALAZAR, Secretary \\ U.S. Geological Survey \\ Marcia K. McNutt, Director}

U.S. Geological Survey, Reston, Virginia: 2010

For more information on the USGS - the Federal source for science about the Earth, its natural and living resources, natural hazards, and the environment, visit http://www.usgs.gov or call 1-888-ASK-USGS

For an overview of USGS information products, including maps, imagery, and publications, visit http://www.usgs.gov/pubprod

To order this and other USGS information products, visit http://store.usgs.gov

Any use of trade, product, or firm names is for descriptive purposes only and does not imply endorsement by the U.S. Government.

Although this report is in the public domain, permission must be secured from the individual copyright owners to reproduce any copyrighted materials contained within this report.

Suggested citation:

Williams, J.H., 2010, Evaluation of well logs for determining the presence of freshwater, saltwater, and gas above the Marcellus Shale in Chemung, Tioga, and Broome Counties, New York: U.S. Geological Survey Scientific Investigations Report 2010-5224, 27 p., at http://pubs.usgs.gov/sir/2010/5224/. 


\section{Contents}

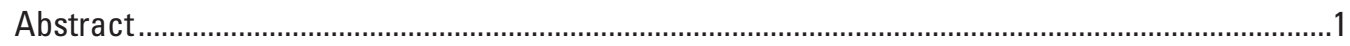

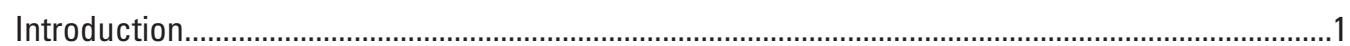

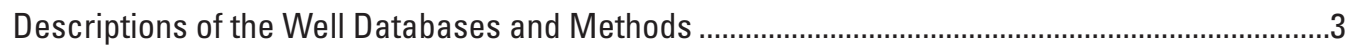

Description of the Geologic Formations ..............................................................................................

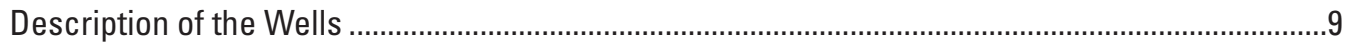

Freshwater, Saltwater, and Gas above the Marcellus Shale .........................................................12

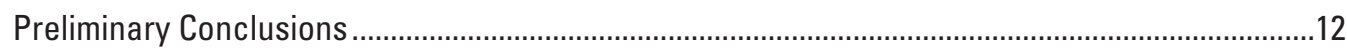

Considerations for Future Water and Gas Logging .................................................................

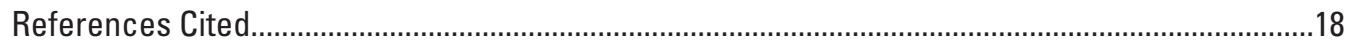

Appendix 1. Log Summary for Water Wells in the National Water Information System that Penetrated Saltwater and (or) Gas in Cheming, Tioga, and Broome Counties, New York, 2010 ..................................................................................................................19

Appendix 2. Log Summary for Gas Wells in the Empire State Oil and Gas System that Penetrated Freshwater, Saltwater, and (or) Gas above the Marcellus Shale in Chemung, Tioga, and Broome Counties, New York, 2010

\section{Figures}

1. Map showing location of Marcellus Shale gas play in New York State and study area in Chemung, Tioga, and Broome Counties.

2. Map showing location of water wells in the U.S. Geological Survey National Water Information System in the study area, 2010

3. Map showing location of gas wells in the New York State Museum Empire State Oil and Gas Information System (ESOGIS) in the study area, 2010

4. Diagram showing generalized north-south section with bedrock formations in south-central New York

5. Map showing surficial geology of the study area, Chemung, Tioga, and Broome Counties, New York

6. Map showing bedrock geology of the study area, Chemung, Tioga, and Broome Counties, New York.

7. Diagrams showing schematics of water-well completions: (A) screened well, $(B)$ open-end well, and (C) open-hole well...

8. Diagrams showing schematics of gas-well completions: (A) vertical well with conductor, surface, and production casings; $(B)$ horizontal well with conductor, surface, intermediate, and production casings; and $(C)$ horizontal well with conductor, surface, and production casings

9. Map showing location of water wells that penetrated saltwater and gas wells that penetrated freshwater in the study area

10. Graphs showing number and depth of freshwater zones penetrated by gas wells in the study area: $(A)$ linear scale and $(B) \log$ scale

11. Map showing location of gas and water wells that penetrated gas above the Marcellus Shale in the study area 
12. Graph showing number and depth of gas zones above the Marcellus Shale penetrated by gas wells in the study area

13. Diagram showing gamma, induction conductivity, caliper, specific conductance, and temperature logs from a water well that penetrated saltwater below 300 feet in Upper Devonian bedrock, western New York.

\section{Conversion Factors, Datums, and Abbreviations}

Inch/Pound to SI

\begin{tabular}{|c|c|c|}
\hline Multiply & By & To obtain \\
\hline \multicolumn{3}{|c|}{ Length } \\
\hline inch (in.) & 2.54 & centimeter $(\mathrm{cm})$ \\
\hline foot $(\mathrm{ft})$ & 0.3048 & meter $(\mathrm{m})$ \\
\hline mile (mi) & 1.609 & kilometer $(\mathrm{km})$ \\
\hline \multicolumn{3}{|c|}{ Flow rate } \\
\hline gallon per minute (gal/min) & 0.06309 & liter per second $(\mathrm{L} / \mathrm{s})$ \\
\hline
\end{tabular}

Temperature in degrees Fahrenheit $\left({ }^{\circ} \mathrm{F}\right)$ may be converted to degrees Celsius $\left({ }^{\circ} \mathrm{C}\right)$ as follows:

$$
{ }^{\circ} \mathrm{C}=\left({ }^{\circ} \mathrm{F}-32\right) / 1.8 \text {. }
$$

Vertical coordinate information is referenced to the National Geodetic Vertical Datum of 1929. Horizontal coordinate information is referenced to the North American Datum of 1983.

Specific conductance of water is given in microsiemens per centimeter $(\mu \mathrm{S} / \mathrm{cm})$.

Concentrations of chemical constituents in water are given in milligrams per liter (mg/L).

Induction conductivity is given in millisiemens per meter $(\mathrm{mS} / \mathrm{m})$.

Gamma is given in counts per second (cps).

\section{ABBREVIATIONS USED IN REPORT}

ESOGIS Empire State Oil and Gas Information System

NWIS National Water Information System

USGS U.S. Geological Survey

NYSM New York State Museum

NYSDEC New York State Department of Environmental Conservation 


\title{
Evaluation of Well Logs for Determining the Presence of Freshwater, Saltwater, and Gas above the Marcellus Shale in Chemung, Tioga, and Broome Counties, New York
}

\author{
By John H. Williams
}

\begin{abstract}
Recent technological advances in horizontal drilling and high-volume hydraulic fracturing have made the Marcellus Shale the newest gas-development target or play in the northern Appalachian basin. Protection of freshwater aquifers from contamination by saltwater and gas during the development of the Marcellus Shale play is an issue of concern. Chemung, Tioga, and Broome Counties are in the southwestern part of the Marcellus Shale play in New York and likely will be the focus of drilling early in development of the play in the State. As a preliminary step in understanding and protecting the groundwater resource in the three-county area, logs of water wells in the U.S. Geological Survey National Water Information System and gas wells in the New York State Museum Empire State Oil and Gas Information System were evaluated for the determination of the presence of freshwater, saltwater, and gas above the Marcellus Shale.

Results of the evaluation of the water- and gas-well logs indicate that freshwater aquifer zones are log normally distributed with depth in the three-county study area and that freshwater circulates to a greater depth in the uplands than in the valleys. The base of the freshwater aquifer appears to be about 800 feet below land surface in upland settings but only about 200 feet below land surface in valley settings. At depths greater than 200 feet in valley settings, groundwater in the Upper Devonian bedrock, and in a few areas in the glacial drift, is salty. Gas is present locally in the glacial drift, Upper Devonian bedrock, Tully Limestone, and Hamilton Group above the Marcellus Shale. The highest rates of gas flow above the Marcellus Shale may be associated with the Tully Limestone. The frequency of gas zones generally increases with depth in the Upper Devonian bedrock with pockets of gas locally present above the base of the freshwater aquifer.

Consistent and complete reporting of freshwater, saltwater, and gas during the drilling of future Marcellus
\end{abstract}

shale-gas wells would greatly improve existing information. Field measurement of specific conductance of water produced during drilling and specific-conductance and temperature wireline geophysical logging of open boreholes prior to surface-casing installation would enhance the value of the gaswell logs. Compilation and integration of information from water wells that are inventoried and sampled for water quality during gas development with data from ongoing county-wide and regional programs would provide an important database for understanding and protecting the freshwater aquifers.

\section{Introduction}

Recent technological advances in horizontal drilling and high-volume hydraulic fracturing have made the Marcellus Shale the newest gas-development target or play in the northern Appalachian basin. Chemung, Tioga, and Broome Counties are in the southwestern part of the Marcellus Shale play in New York and likely will be the focus of drilling early in development of the play in the State (fig. 1). Protection of freshwater aquifers from contamination by saltwater and gas during the development of the Marcellus Shale play is an issue of concern. As a preliminary step in understanding and protecting the groundwater resource, logs of water wells and gas wells in the three-county area were evaluated for the determination of the presence of freshwater, saltwater, and gas above the Marcellus Shale.

This report describes the geologic formations and waterand gas-well completions in Chemung, Tioga, and Broome Counties, New York. A preliminary determination of the presence of freshwater, saltwater, and gas above the Marcellus Shale in the study area based on an evaluation of water- and gas-well logs is presented. Considerations for future water and gas logging during the drilling of Marcellus gas wells also are discussed. 


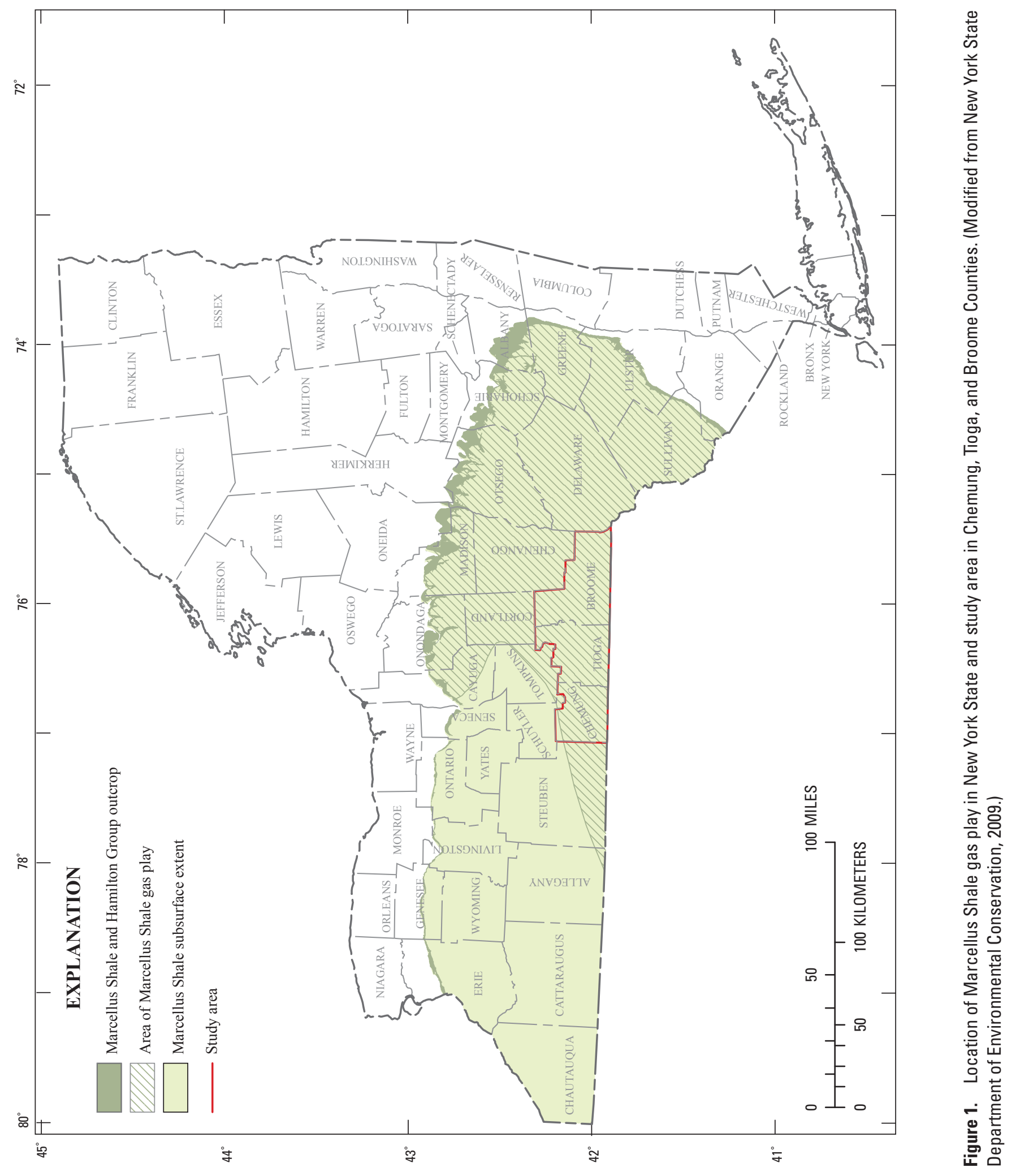




\section{Descriptions of the Well Databases and Methods}

Well logs were compiled from two databases, the U.S. Geological Survey (USGS) National Water Information System (NWIS) and the New York State Museum (NYSM) Empire State Oil and Gas Information System (ESOGIS). The NWIS, which is maintained by the USGS New York Water Science Center, stores water-well logs that can be retrieved online from http://waterdata.usgs.gov/nwis/inventory. The ESOGIS, which is maintained by the NYSM Reservoir Characterization Group, stores oil- and gas-well logs that can be retrieved online from http://esogis.nysm.nysed.gov/.

Logs for more than 1,450 water wells stored in the NWIS (fig. 2) and logs for about 350 gas wells stored in the ESOGIS (fig. 3) were reviewed to obtain information on well completions, geologic formations penetrated by the wells, and the presence of freshwater, saltwater, and gas above the Marcellus Shale in the three-county study area. Most of the water wells recorded in the NWIS and almost all of the 55 sites at which saltwater and (or) gas were present in the groundwater (appendix 1) were inventoried by Randall (1972) as part of valley-fill aquifer investigations in the 1960s and 1970s. The presence of saltwater was reported by drillers or well owners based on taste tests or was determined by waterquality analyses that indicated a chloride concentration of greater than $250 \mathrm{mg} / \mathrm{L}$. The presence of gas was reported by drillers or well owners or was observed during field inventory.

The gas-well logs in the ESOGIS are for single- and multiple-well sites, wells whose confidential status had not expired (typically 2 years), and permitted but uncompleted wells. Because the formations above the Marcellus Shale have not been the focus of gas exploration, many of the gas-well logs contain little or no information on this stratigraphic interval. Ninety-three of the gas-well logs report penetration of water and (or) gas zones above the Marcellus Shale (appendix 2). Water flows were reported by gas-well drillers as freshwater or saltwater presumably based on taste tests. Water flows commonly were rated by the gas-well drillers in inches of the stream discharging from an open pipe into a mud pit while drilling with air. Reportedly, a 1-inch stream roughly equates to a flow of 10 to $20 \mathrm{gal} / \mathrm{min}$, and a 2-inch stream roughly equates to a flow of 40 to $50 \mathrm{gal} / \mathrm{min}$. Gas-flow rates generally were not quantified; those that were rated were reported in MCF (1,000 cubic feet), which presumably equates to the flow rate per day.

The spatial and stratigraphic distributions of freshwater, saltwater, and gas above the Marcellus Shale were investigated through an analysis of the water- and gas-well logs. Geographic Information System (GIS) coverages and histograms of the well data were created using ARCGIS software to aid in this preliminary delineation.

\section{Description of the Geologic Formations}

South-central New York is underlain by sedimentary bedrock of Cambrian, Ordovician, Silurian, and Devonian age (fig. 4). The sedimentary bedrock gently dips to the south and is underlain by Precambrian crystalline bedrock. A deep exploratory well in Chemung County, purportedly the deepest cable-tool hole in the world at the time (1953), penetrated more than $11,000 \mathrm{ft}$ of sedimentary bedrock, including $600 \mathrm{ft}$ of the basal Cambrian formations.

Glacial drift, including till and stratified deposits, discontinuously overlies the sedimentary bedrock in the study area. Till, an unsorted mixture of clay, silt, sand, and boulders, mantles the uplands. Stratified drift of lacustrine silt and clay, outwash sand and gravel, and ice-contact deposits fills the glacially scoured valleys (fig. 5). An extensive and thick deposit of moraine, which consists mostly of till and lacustrine silt and clay with scattered sand and gravel, is present in northwestern Chemung County. Saturated deposits of sand and gravel in the valleys form major aquifers that supply freshwater to small and large communities and base flow to streams. Although the valley fill reaches thicknesses of greater than $500 \mathrm{ft}$, the total thickness of saturated sand and gravel rarely exceeds $50 \mathrm{ft}$. More detailed information on the valleyfill aquifers in the study area is presented by Randall (1972), MacNish and Randall (1982), Randall and others (1988), and Miller (1988).

Sedimentary bedrock of Upper Devonian age underlies the study area (fig. 6). Sandstone, siltstone, and shale of the Java Group crop out in the southwestern corner of Chemung County. The shale, siltstone, and sandstone of the West Falls Group crop out in Chemung and Tioga Counties and the southern part of Broome County. Shale and siltstone of the Sonyea and Genesse Groups crop out in the northern part of Broome County and in the northernmost valleys of Tioga and Chemung Counties. Each of these formations generally coarsens upward and to the east. The Upper Devonian formations form a fractured-bedrock aquifer that supplies freshwater to many farms, rural homes, and small communities, as well as base flow to streams. Additional information on the Upper Devonian bedrock aquifers just to the south of the study area in Pennsylvania is presented by Williams and others (1998).

The Tully Limestone (fig. 4), a key stratigraphic marker bed whose top is delineated in almost all of the gas-well logs, underlies the Upper Devonian bedrock. Below the Tully Limestone are shales and calcareous sandstones of the Hamilton Group. At the base of the Hamilton Group is the Marcellus Shale, a black, organic-rich shale. Although gas has been produced from the Marcellus Shale in New York since 1931, the combination of horizontal drilling with high-volume hydraulic fracturing has made this formation the latest "hot" prospect in the State. 


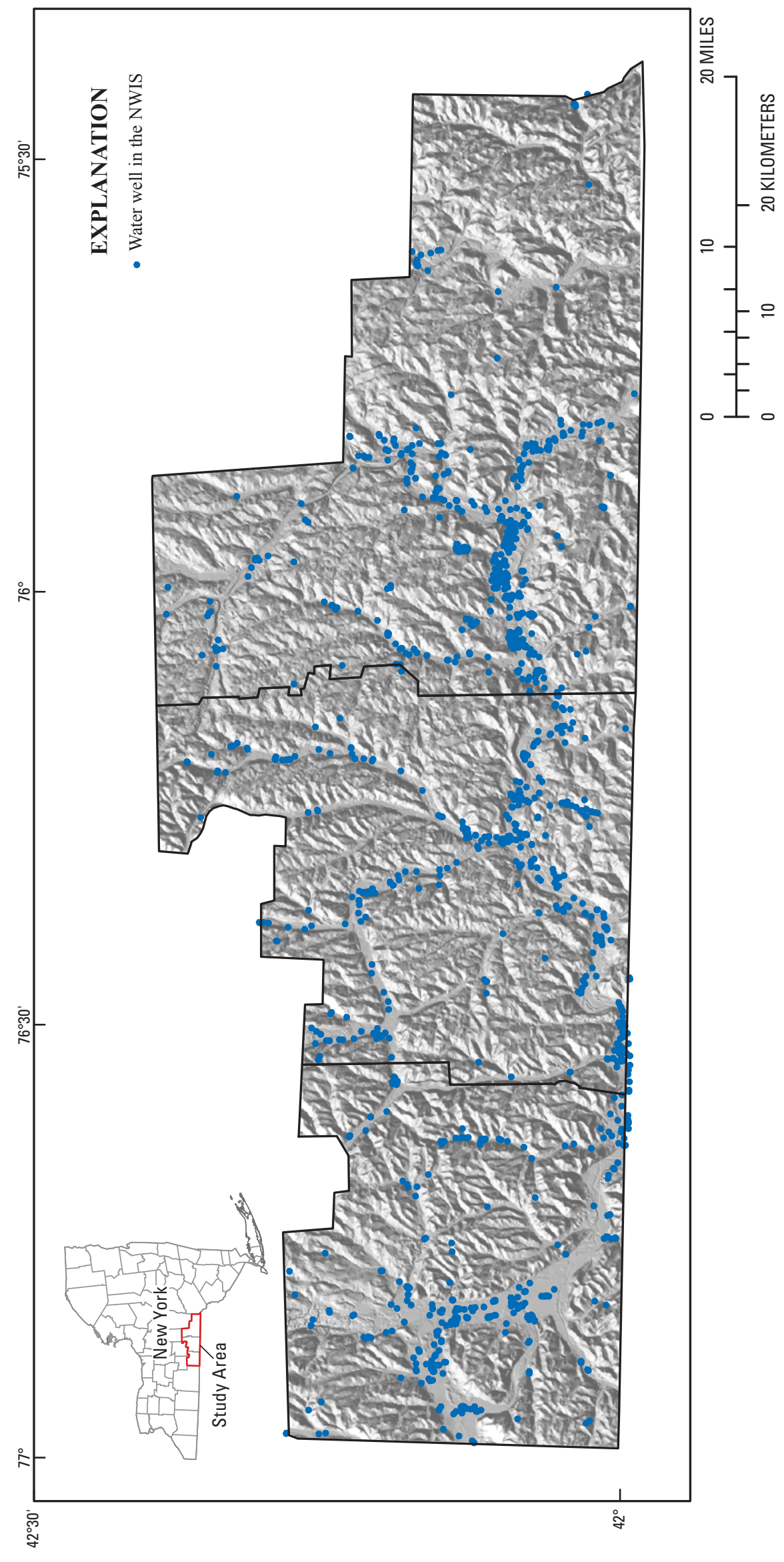

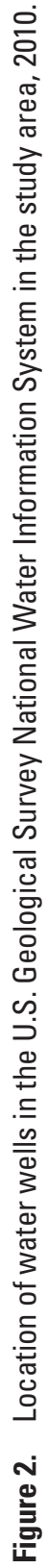




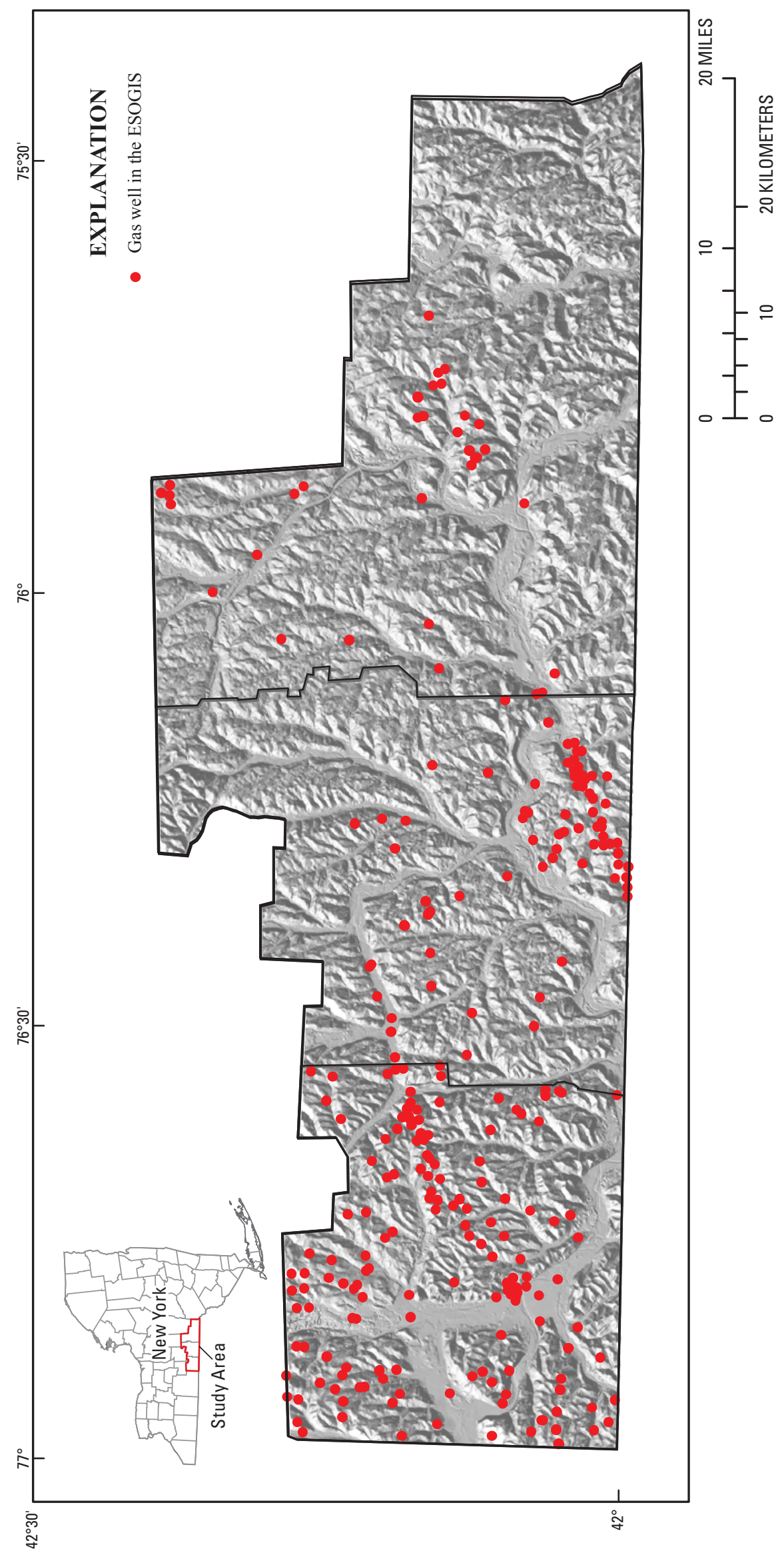

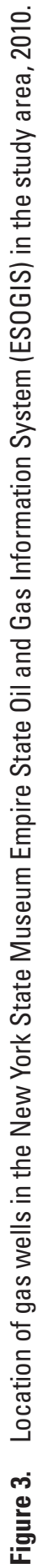




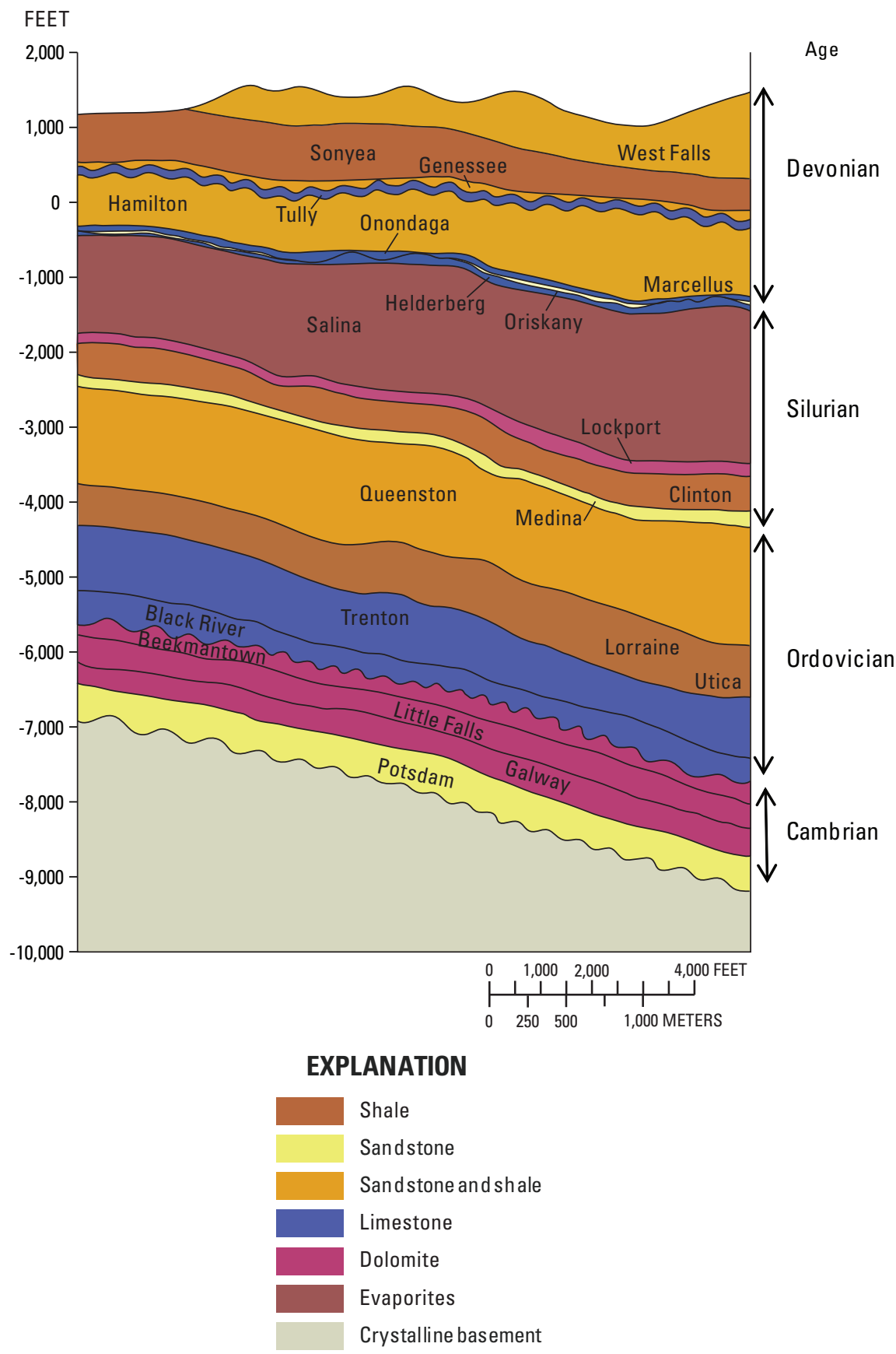

Figure 4. Generalized north-south section with bedrock formations in south-central New York. (Modified from New York State Museum, 2009.) 


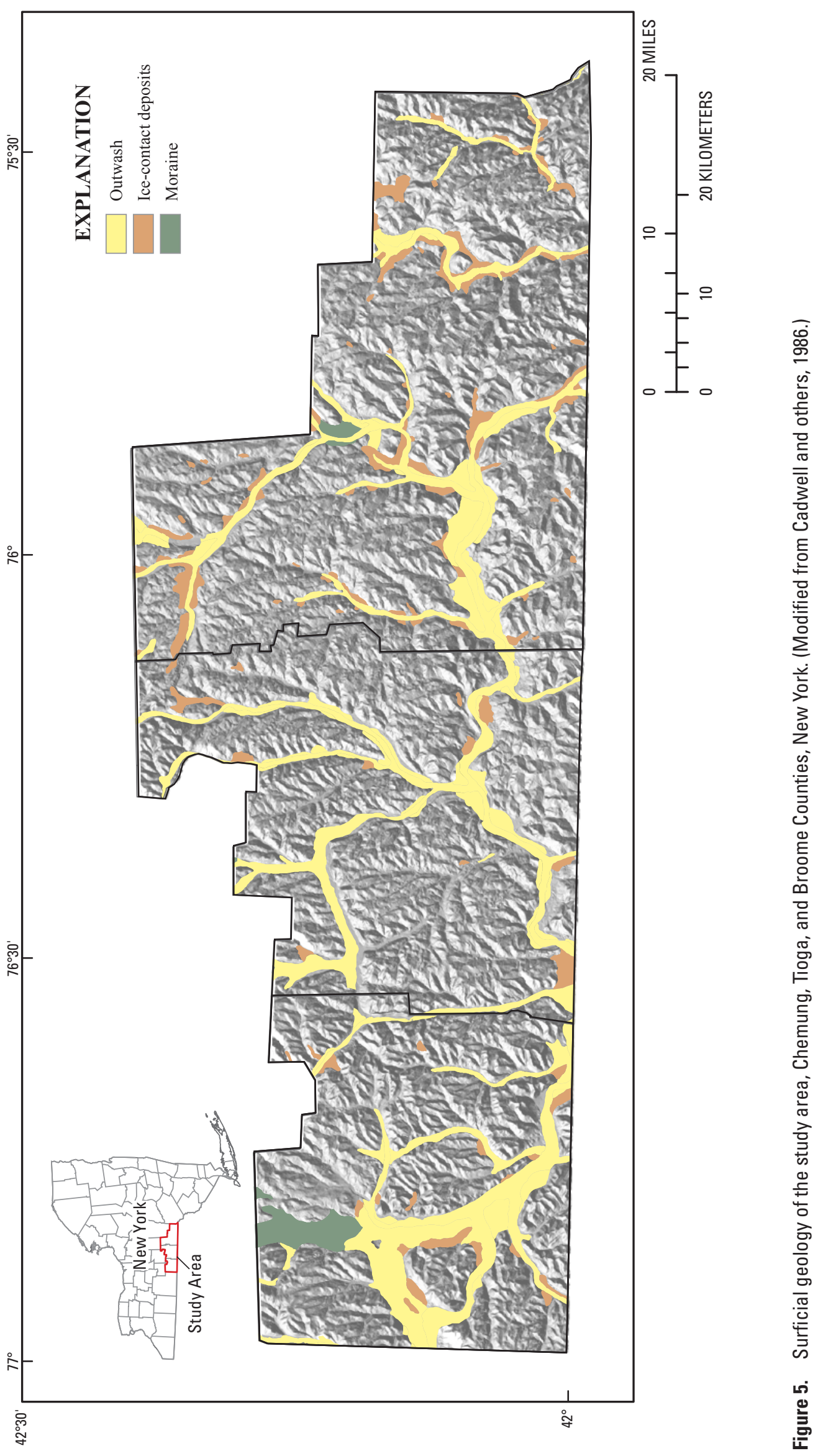




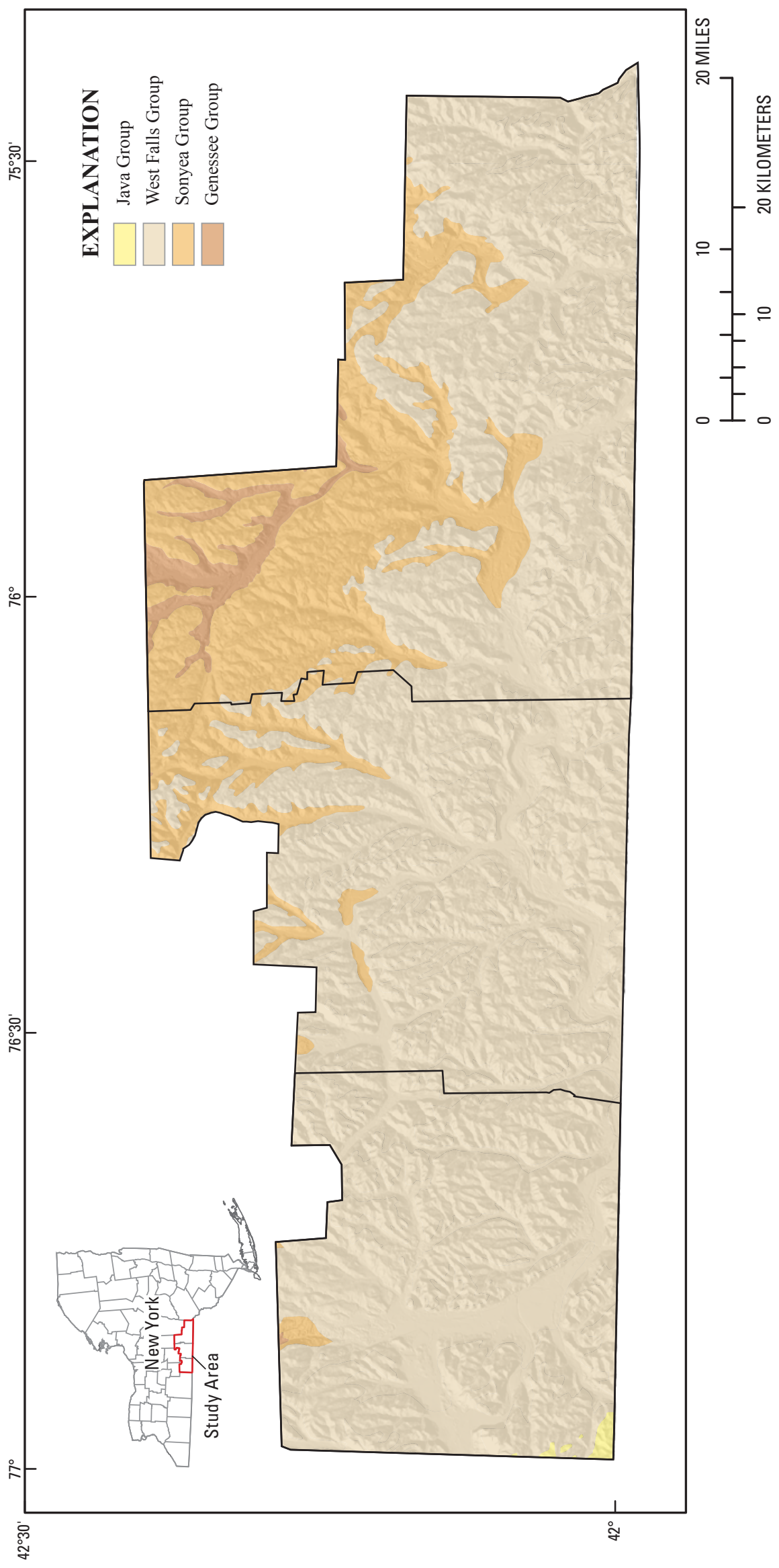

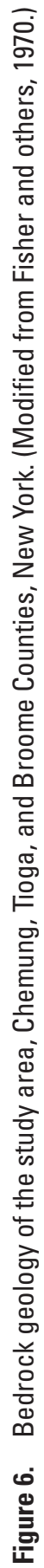


Historically, gas production in the study area mainly has been from three formations that lie below the Marcellus Shale - the Oriskany, Helderberg, and Trenton-Black River. The Oriskany Sandstone of Lower Devonian age is typically a fossiliferous, quartz-rich sandstone cemented with quartz or calcite. The Oriskany, which has intergranular and fracture porosity, has been a widespread gas producer in New York and throughout the Appalachian basin. Many of the exploration wells completed in the Oriskany produced saltwater in addition to, or instead of, gas. The carbonate rocks of the Helderberg Group, also of Lower Devonian age, lies below the Oriskany Sandstone and locally have been an important gas producer. Deep gas reservoirs have been developed in the Upper Ordovician Trenton and Black River Groups in patchy dolomite matrix and brecciated zones along faultrelated structural lows. The Utica Shale, which lies above the Trenton and Black River Groups, is a black, organic-rich shale that is receiving considerable interest as a low-permeability unconventional gas play similar to that of the Marcellus Shale.

\section{Description of the Wells}

Water wells in the study area are completed in glacial drift or the Upper Devonian bedrock. Municipal-supply and other high-yield wells are screened in glacial sand-and-gravel aquifers commonly present along river and major stream valleys (fig. 7). Farm- and home-use wells tap sand-and-gravel aquifers through open-end casing. Wells that tap bedrock are cased to competent rock and completed as open holes.

Until 2000, gas wells in the study area were drilled as vertical boreholes. Since then, many have been completed as horizontal wells to maximize production from target horizons. Both vertical (fig. 8A) and horizontal (figs. 8B-C) wells have multiple casings. The uppermost casing is called the conductor casing and is set to competent bedrock to provide for stable drilling conditions. The next casing interval is the surface casing, which is set to a prescribed depth below the freshwater aquifer. The wellbore annular spacing is cemented from the base of the surface casing to land surface. If drilling conditions dictate, an intermediate casing may be set inside the surface casing (fig. 8B). Finally, the production casing is set inside the surface casing, and if present, the intermediate casing, to the targeted gas horizon. The wellbore annular spacing of the intermediate and production casings typically has been cemented one to several thousand feet above the base of the casings (figs. 8A-B). As presently drafted, the New York State Department of Environmental Conservation (NYSDEC) regulations for horizontal wells with high-volume hydraulic fracturing in shale will require that the production casing be cemented to land surface (fig. 8C) if no intermediate casing is installed (New York State Department of Environmental Conservation, 2009).
A Screened well

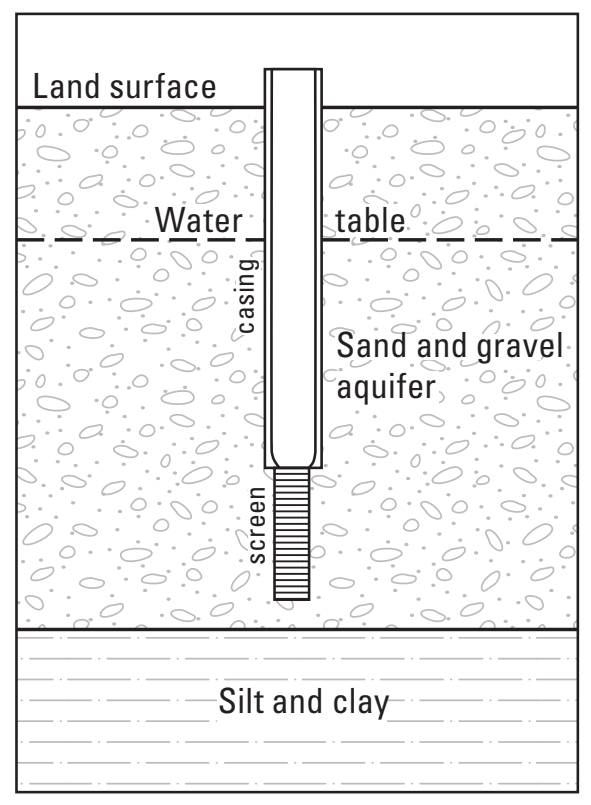

B Open-end well

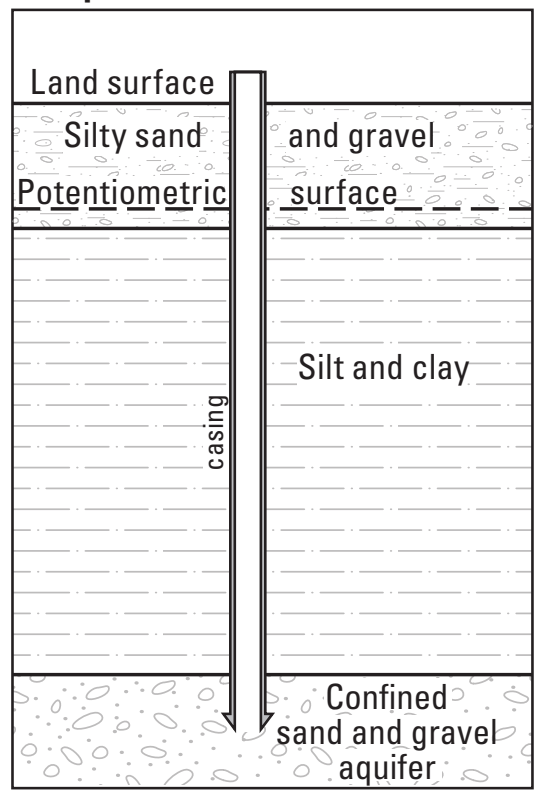

C Open-hole well

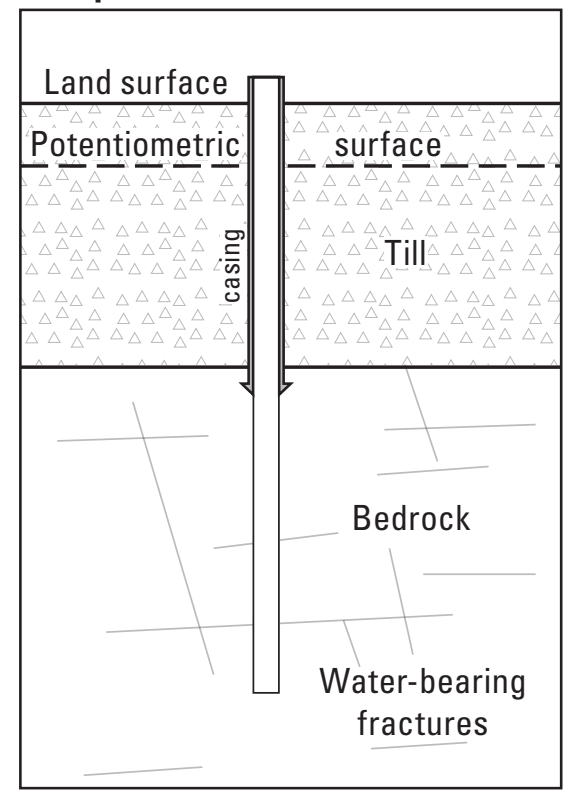

Figure 7. Schematics of water-well completions: $(A)$ screened well, $(B)$ open-end well, and $(C)$ open-hole well (Modified from Williams and others, 1998). 
$\boldsymbol{A}$

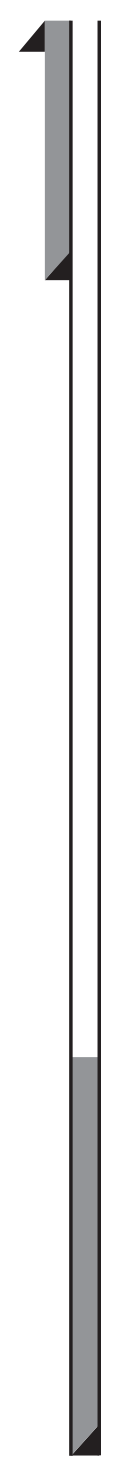

B

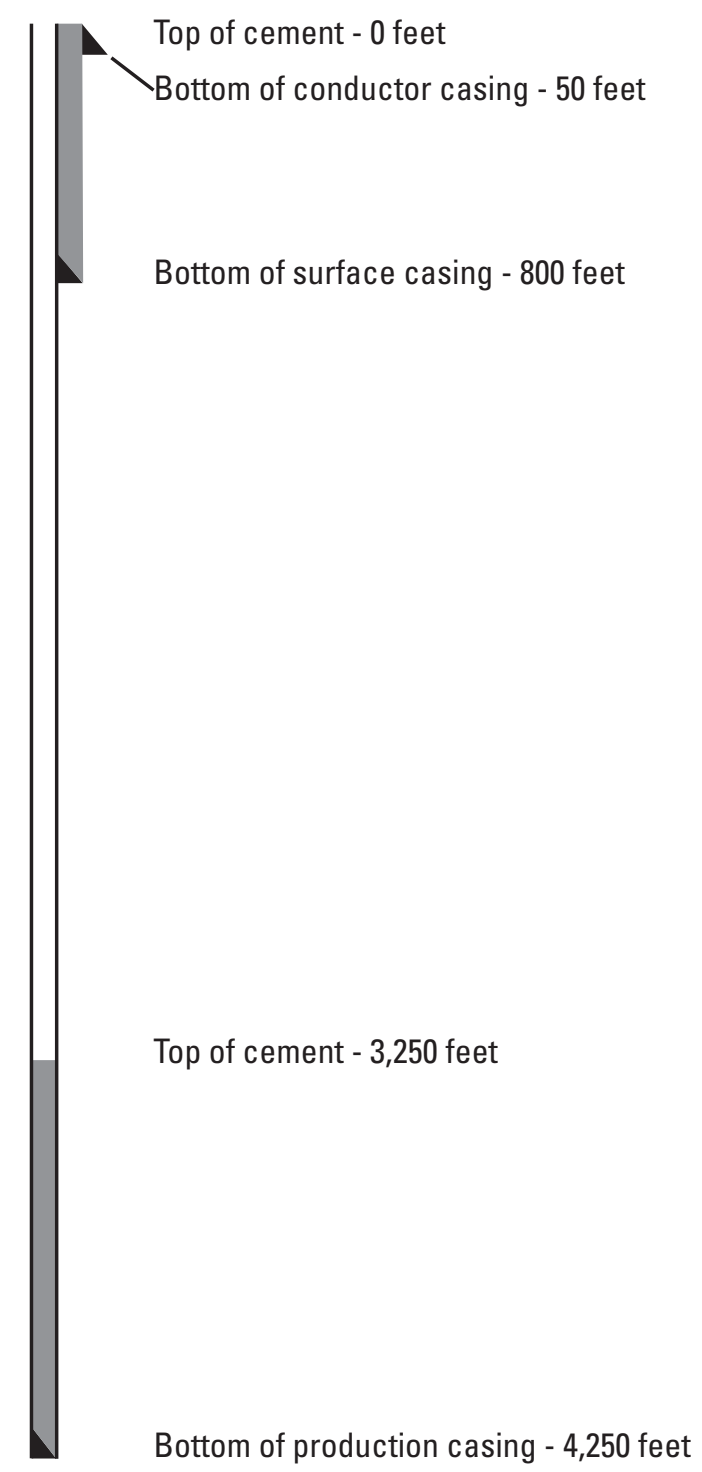

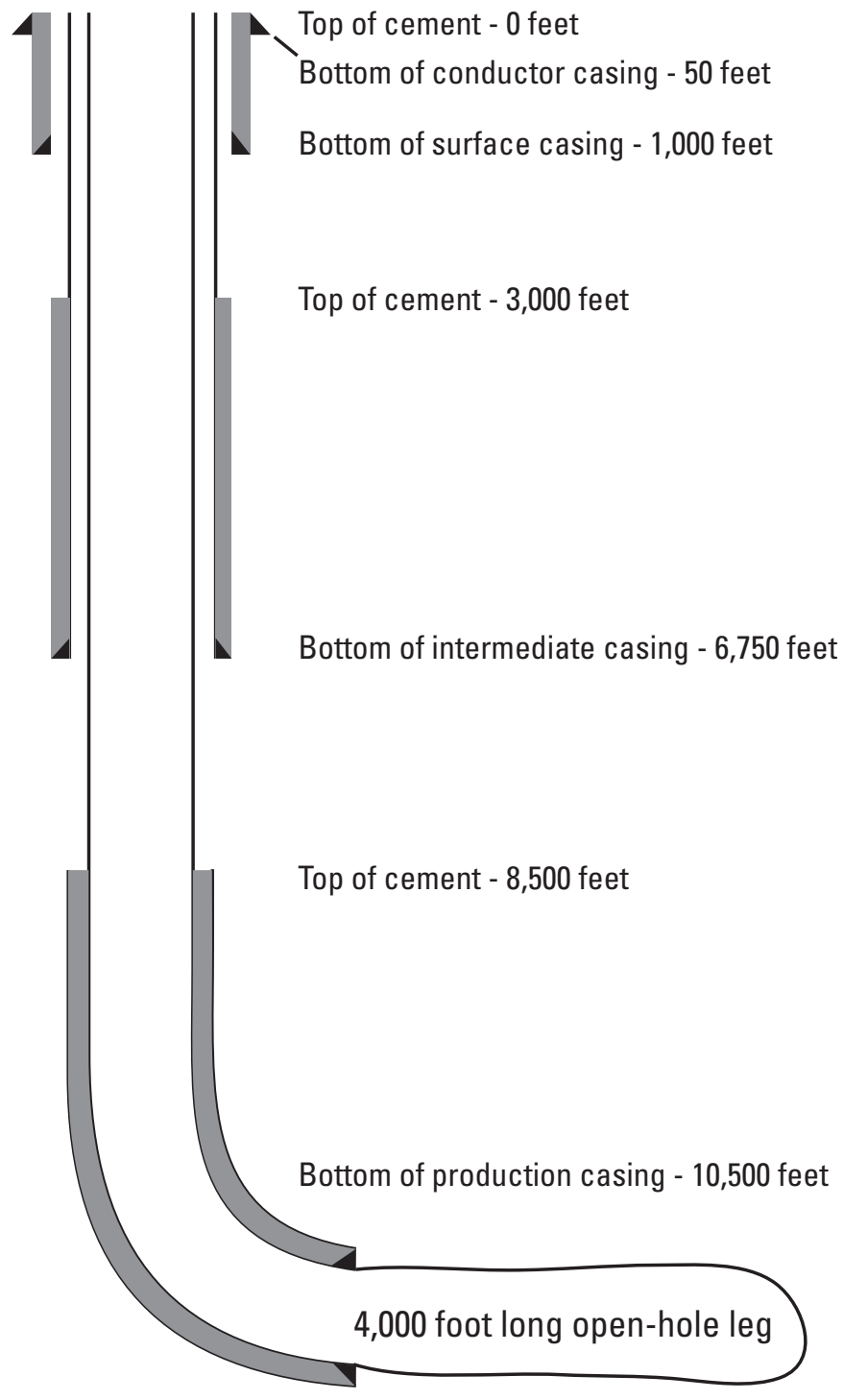

Figure 8. Schematics of gas-well completions: $(A)$ vertical well with conductor, surface, and production casings; $(B)$ horizontal well with conductor, surface, intermediate, and production casings; and (C) horizontal well with conductor, surface, and production casings. 


\section{C}

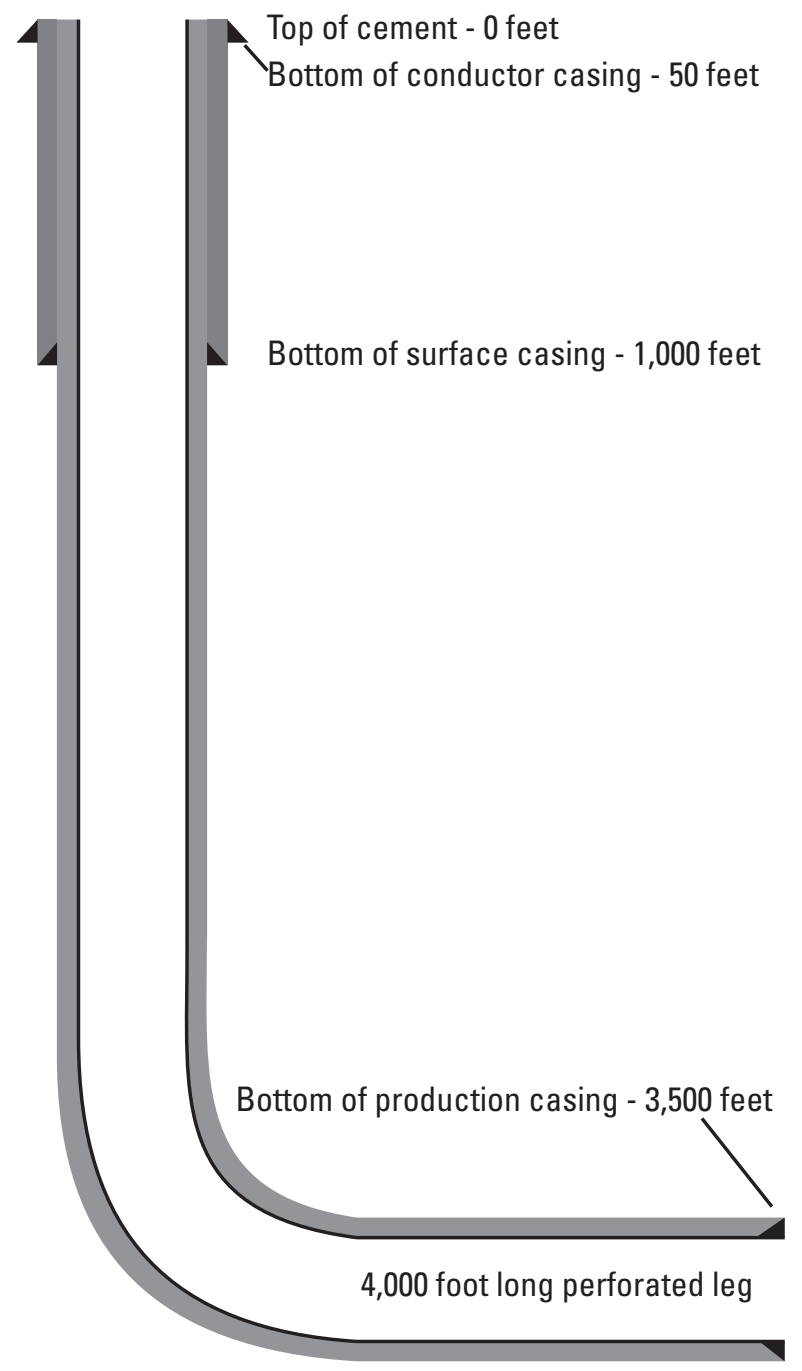

Figure 8. Schematics of gas-well completions: $(A)$ vertical well with conductor, surface, and production casings; $(B)$ horizontal well with conductor, surface, intermediate, and production casings; and $(C)$ horizontal well with conductor, surface, and production casings.-Continued 


\section{Freshwater, Saltwater, and Gas above the Marcellus Shale}

The presence and distribution of freshwater, saltwater, and gas above the Marcellus Shale were investigated through analysis of the water- and gas-well logs (appendixes 1 and 2). Seventy-four gas wells penetrated 123 freshwater zones in glacial drift and Upper Devonian bedrock at depths of 12 to $784 \mathrm{ft}$ below land surface (fig. 9). About 75 percent of the freshwater zones were penetrated at depths of $150 \mathrm{ft}$ or less below land surface (fig. 10). The distribution of the freshwater-zone depths approached a log-normal distribution. Nine of the 10 gas wells that penetrated freshwater at depths greater than $500 \mathrm{ft}$ below land surface are in upland bedrock settings. The one exception is a gas well that penetrated a highly confined sand-and-gravel aquifer buried beneath $700 \mathrm{ft}$ of morainal deposits, which consist of lacustrine silt and clay with some till near land surface.

Forty-six water wells penetrated saltwater zones at depths of 56 to $520 \mathrm{ft}$ below land surface (fig. 9). Two of these wells penetrated saltwater in glacial drift; the rest penetrated saltwater in Upper Devonian bedrock. Most of the salty water wells penetrated saltwater zones in the Upper Devonian bedrock at depths of 140 to $260 \mathrm{ft}$ below land surface. All the water wells that penetrated saltwater were in river, major stream, or upland-tributary valleys. Sixteen gas wells penetrated saltwater at depths of 500 to $3,400 \mathrm{ft}$ below land surface. Thirteen gas wells penetrated saltwater in Upper Devonian bedrock; most of these saltwater zones are at depths between 1,500 and 2,000 ft below land surface. Three gas wells penetrated saltwater in the Tully Limestone and Hamilton Group above the Marcellus Shale.

Thirty-two gas wells penetrated 49 gas zones above the Marcellus Shale at depths of 263 to 2,281 ft below land surface (figs. 11 and 12). Eighty percent of the gas zones are in the Upper Devonian bedrock, and the rest are in the Tully Limestone and Hamilton Group above the Marcellus Shale. The frequency of gas zones increased with increasing depth to about $1,500 \mathrm{ft}$. Of the six gas zones that were rated, which likely correspond to higher flow shows, four are in the Tully Limestone. Ten water wells penetrated gas at depths of 49 to $438 \mathrm{ft}$ below land surface. Two of these wells penetrated gas in glacial drift, the rest penetrated gas in Upper Devonian bedrock.

\section{Preliminary Conclusions}

Well logs in the ESOGIS and NWIS databases provide a preliminary but incomplete determination of freshwater, saltwater, and gas above the Marcellus Shale in the study area. Results of the evaluation of the well logs indicate that freshwater aquifer zones are log normally distributed with depth and that freshwater circulates to a greater depth in the uplands than in the valleys. The base of the freshwater aquifer appears to be about $800 \mathrm{ft}$ below land surface in upland settings but only about $200 \mathrm{ft}$ below land surface in valley settings. At depths greater than $200 \mathrm{ft}$ in valley settings, groundwater in the Upper Devonian bedrock and in a few areas in the glacial drift is salty. Gas is present locally in the glacial drift, Upper Devonian bedrock, Tully Limestone, and Hamilton Group above the Marcellus Shale. The highest rates of gas flow above the Marcellus Shale may be associated with the Tully Limestone. The frequency of gas shows generally increases with depth in the Upper Devonian bedrock with pockets of gas locally present above the base of the freshwater aquifer. 


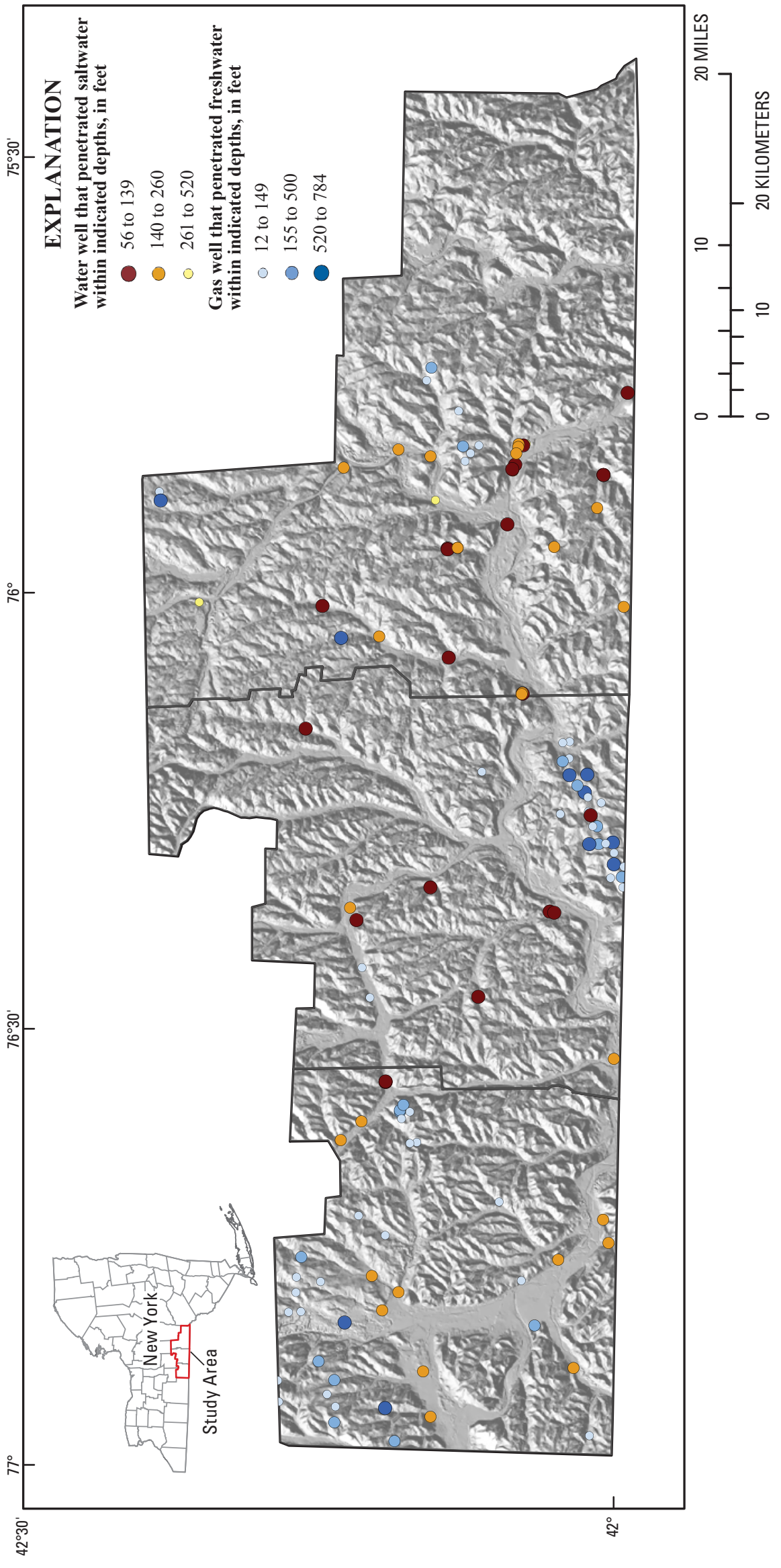

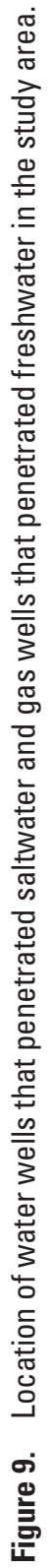



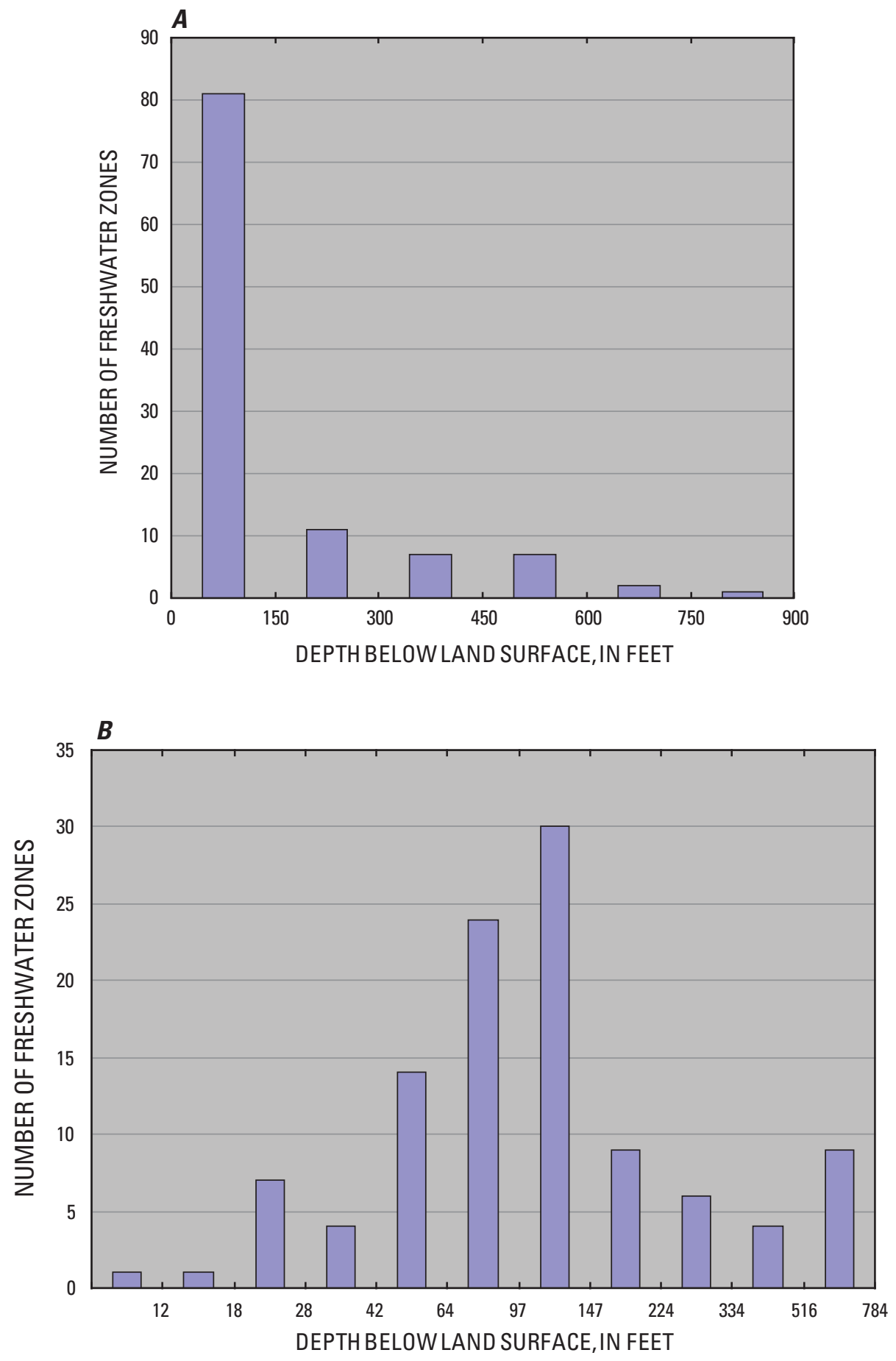

Figure 10. Number and depth of freshwater zones penetrated by gas wells in the study area: $(A)$ linear scale and $(B) \log$ scale. 


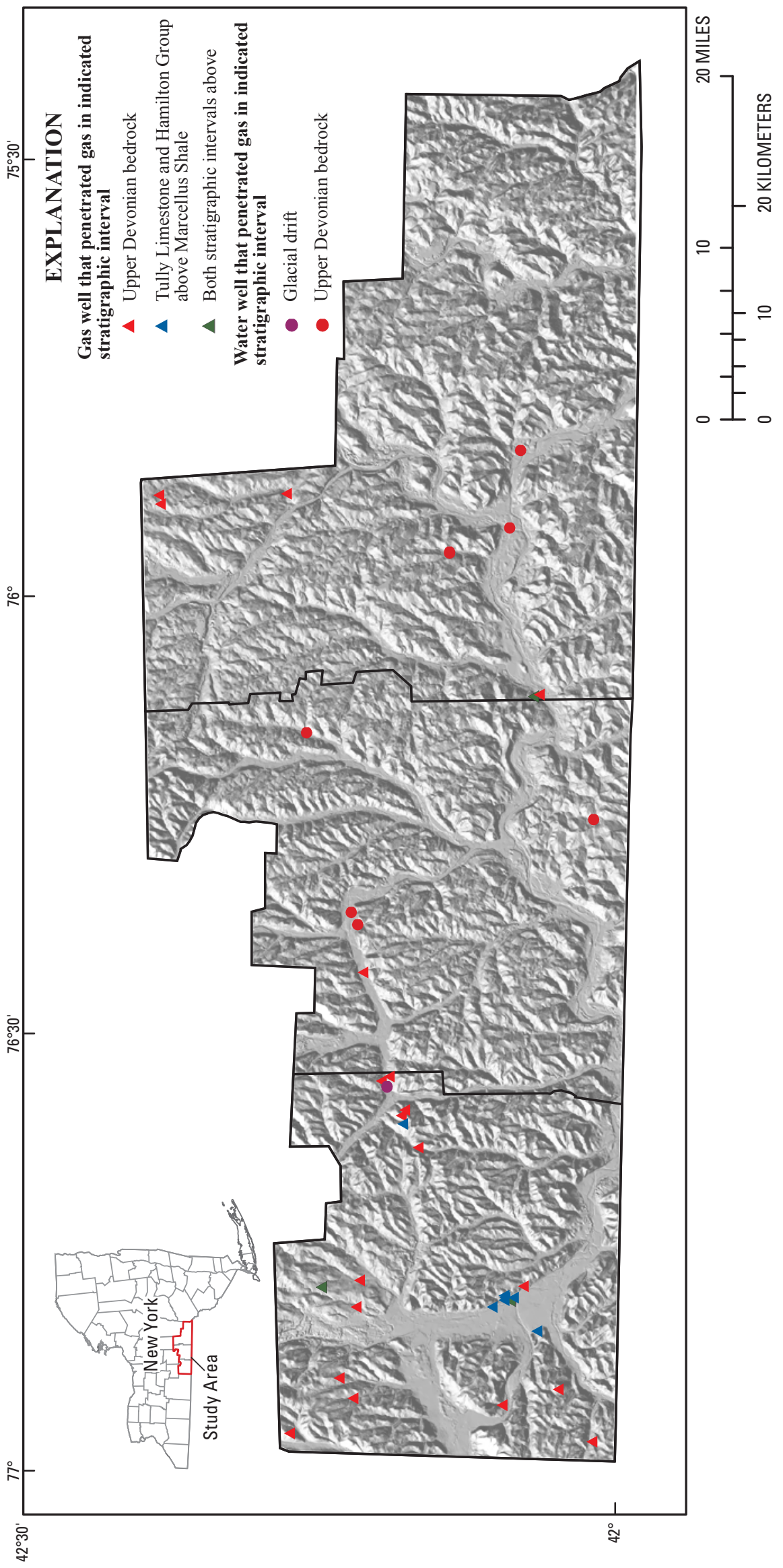

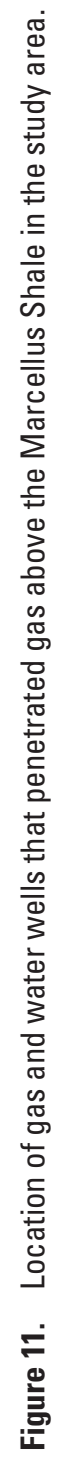




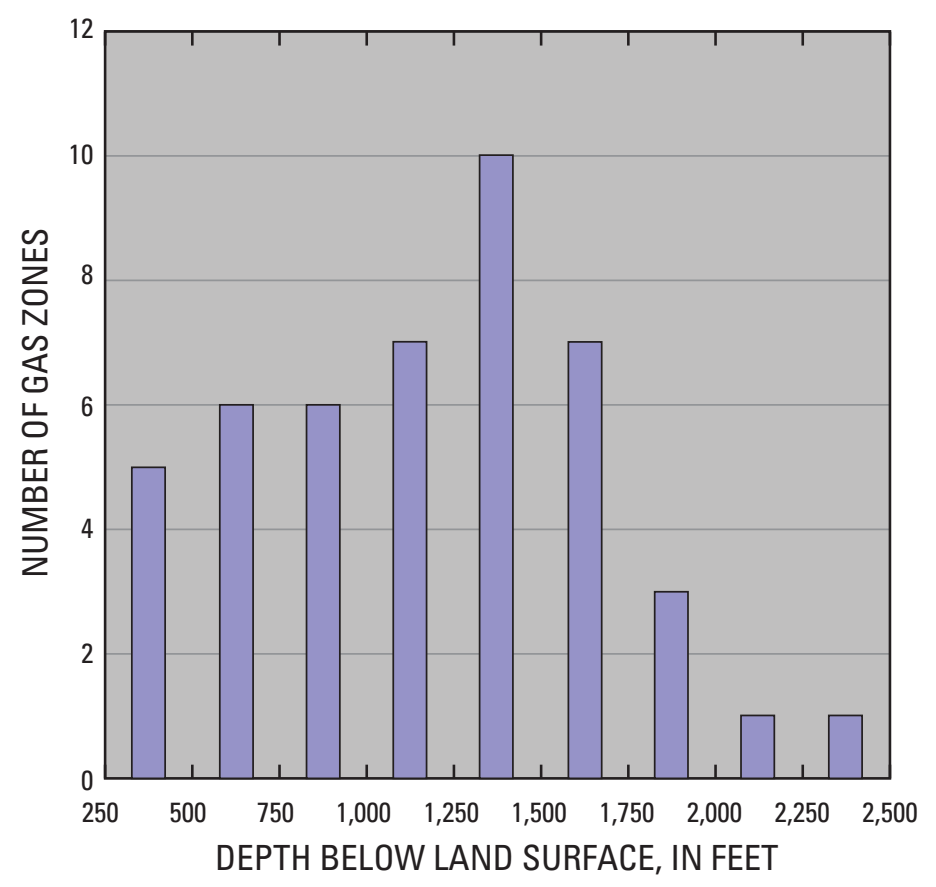

Figure 12. Number and depth of gas zones above the Marcellus Shale penetrated by gas wells in the study area.

\section{Considerations for Future Water and Gas Logging}

In the future, extensive drilling likely will occur in the Marcellus Shale play in New York, including areas in the eastern part that have not undergone any substantial gas development to date. Consistent and complete reporting of freshwater, saltwater, and gas during the drilling of Marcellus Shale gas wells would greatly expand the existing databases. Measurement and reporting of field specific conductance of water produced during drilling would enhance the value of the gas-well logs that presently only classify the water as fresh or salty. Specific-conductance and temperature logging of open boreholes prior to surface-casing installation with a portable, wireline geophysical logger commonly used in the groundwater industry (fig. 13) would be an efficient and highly sensitive means to help delineate freshwater, saltwater, and gas shows at Marcellus Shale gas-drilling sites.

As presently drafted (2010), NYSDEC regulations for horizontal gas wells with high-volume hydraulic fracturing in shale require that water wells within $1,000 \mathrm{ft}$ of the gasdrilling sites (or 2,000 if no wells are present within 1,000 ft) be sampled before drilling and at 3-month intervals for a year following fracturing operations (New York State Department of Environmental Conservation, 2009). The presence of nearby water wells is to be determined by review of available water-well logs along with field inventory. In addition to the well data available in the NWIS, the NYSDEC Water Well Program (available online at http://www.dec.ny.gov/ lands/33317.html) stores location and construction records for water wells drilled since 2000 . The water-quality samples from the selected water wells are to be analyzed for a wide range of constituents, including potential gas-drilling related contaminants such as chloride, barium, gross alpha activity, and methane. Compilation and integration of the water-well records and water-quality analyses related to gas development with other data from county-wide and regional sampling programs, such as the NYSDEC-USGS rotating basin project (Hetcher-Aguila, 2005; Hetcher-Aguila and Eckhardt, 2006; Nystrom, 2007; 2008), would provide an important database for documenting baseline conditions and any potential effects from drilling and hydraulic fracturing. These data could be made available to all agencies, gas producers, and the general public with the ultimate goal of promoting the understanding and protection of the freshwater aquifers in the Marcellus Shale play area. 


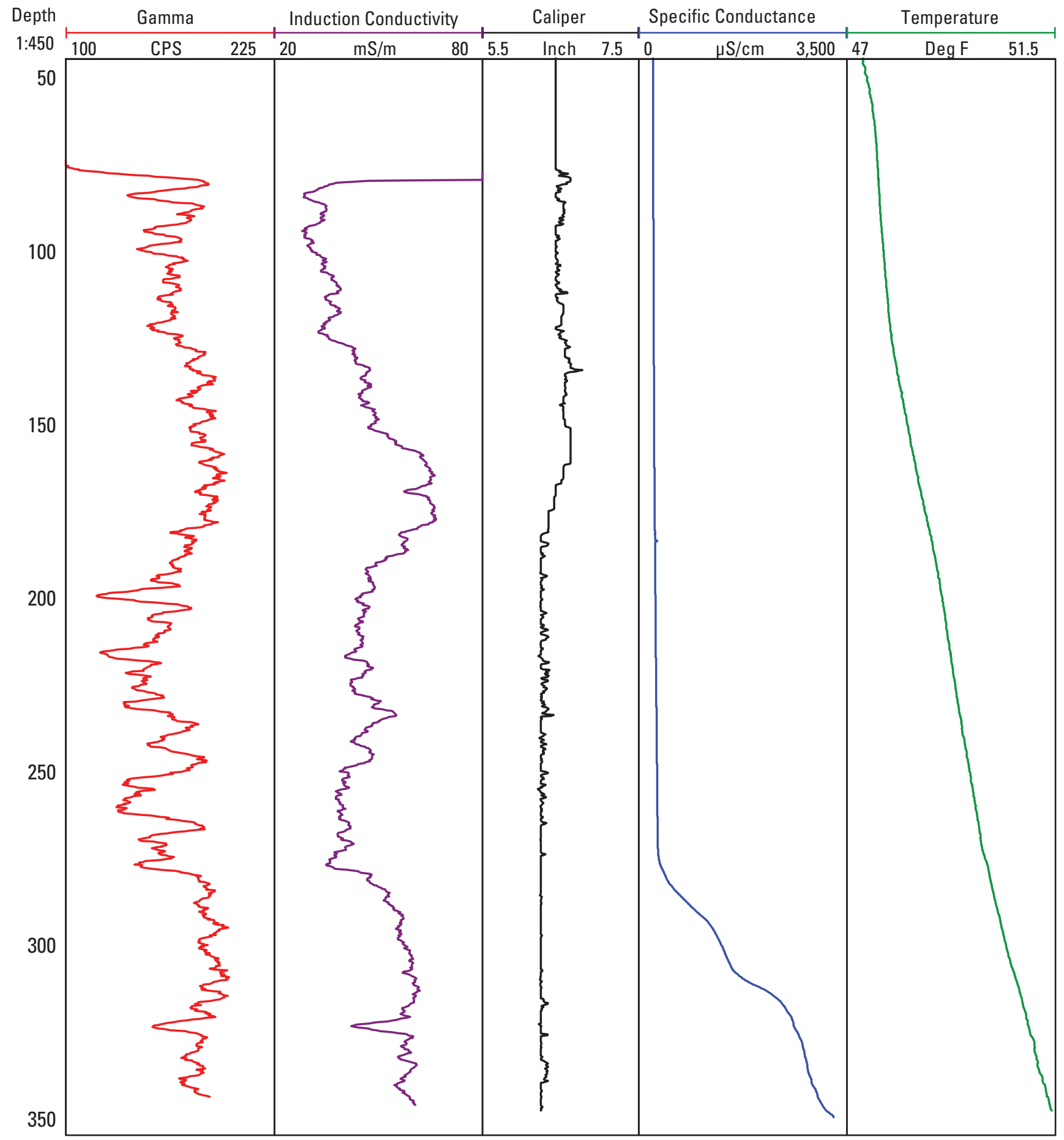

Figure 13. Gamma, induction conductivity, caliper, specific conductance, and temperature logs from a water well that penetrated saltwater below 300 feet in Upper Devonian bedrock, western New York. 


\section{References Cited}

Cadwell, D.H., and others, 1986, Surficial geologic map of New York: New York State Museum and Science Service Map and Chart Series No. 40, 1:250,000 scale.

Fisher, D.W., Isachsen, Y.W., and Rickard, L.V., 1970, Geologic map of New York: New York State Museum and Science Service Map and Chart Series No. 15, 1:250,000 scale.

Hetcher-Aguila, K.K., 2005, Ground-water quality in the Chemung River Basin, New York, 2003: U.S. Geological Survey Open-File Report 2004-1329, 19 p.

Hetcher-Aguila, K.K., and Eckhardt, D.A.V., 2006, Ground-water quality in the upper Susquehanna River Basin, New York, 2004-05: U.S. Geological Survey Open-File Report 2006-1161, 21 p.

MacNish, R.D., and Randall, A.D., 1982, Stratified-drift aquifers in the Susquehanna River basin, New York: New York State Department of Environmental Conservation Bulletin 75, 68 p.

Miller, T.S., 1988, Unconsolidated aquifers in upstate New York-Finger Lakes sheet: U.S. Geological Survey WaterResources Investigations Report 87-4122, 1:250,000 scale.

New York State Department of Environmental Conservation, 2009, Draft Supplemental Generic Environmental Impact Statement on the Oil, Gas and Solution Mining Regulatory Program-Well permit issuance for horizontal drilling and high-volume hydraulic fracturing to develop the Marcellus Shale and other low-permeability gas reservoirs: Albany, NY, New York State Department of Environmental Conservation.
New York State Museum Reservoir Characterization Group, 2009, Schematic north-south cross section Finger Lakes Region of New York State: Albany, NY, New York State Museum Reservoir Characterization Group.

Nystrom, E.A., 2007, Ground-water quality in the Delaware River Basin, New York, 2001 and 2005-06: U.S. Geological Survey Open-File Report 2007-1098, 37 p.

Nystrom, E.A., 2008, Ground-water quality in the Mohawk River Basin, New York, 2006: U.S. Geological Survey Open-File Report 2008-1086, 33 p.

Randall, A.D., 1972, Records of wells and test borings in the Susquehanna River basin, New York: New York State Department of Environmental Conservation Bulletin 69, $92 \mathrm{p}$.

Randall, A.D., Snavely, D.S., Holecek, T.P., and Waller, R.M., 1988, Alternate sources of large seasonal ground-water supplies in the headwaters of the Susquehanna River basin, New York: U.S. Geological Survey Water-Resources Investigations Report 85-4127, $121 \mathrm{p}$.

Williams, J.H., Taylor, L.E., and Low, D.J., 1998, Hydrogeology and groundwater quality of the glaciated valleys of Bradford, Tioga, and Potter Counties, Pennsylvania: Pennsylvania Topographic and Geologic Survey Water Resources Report 68, 89 p. 


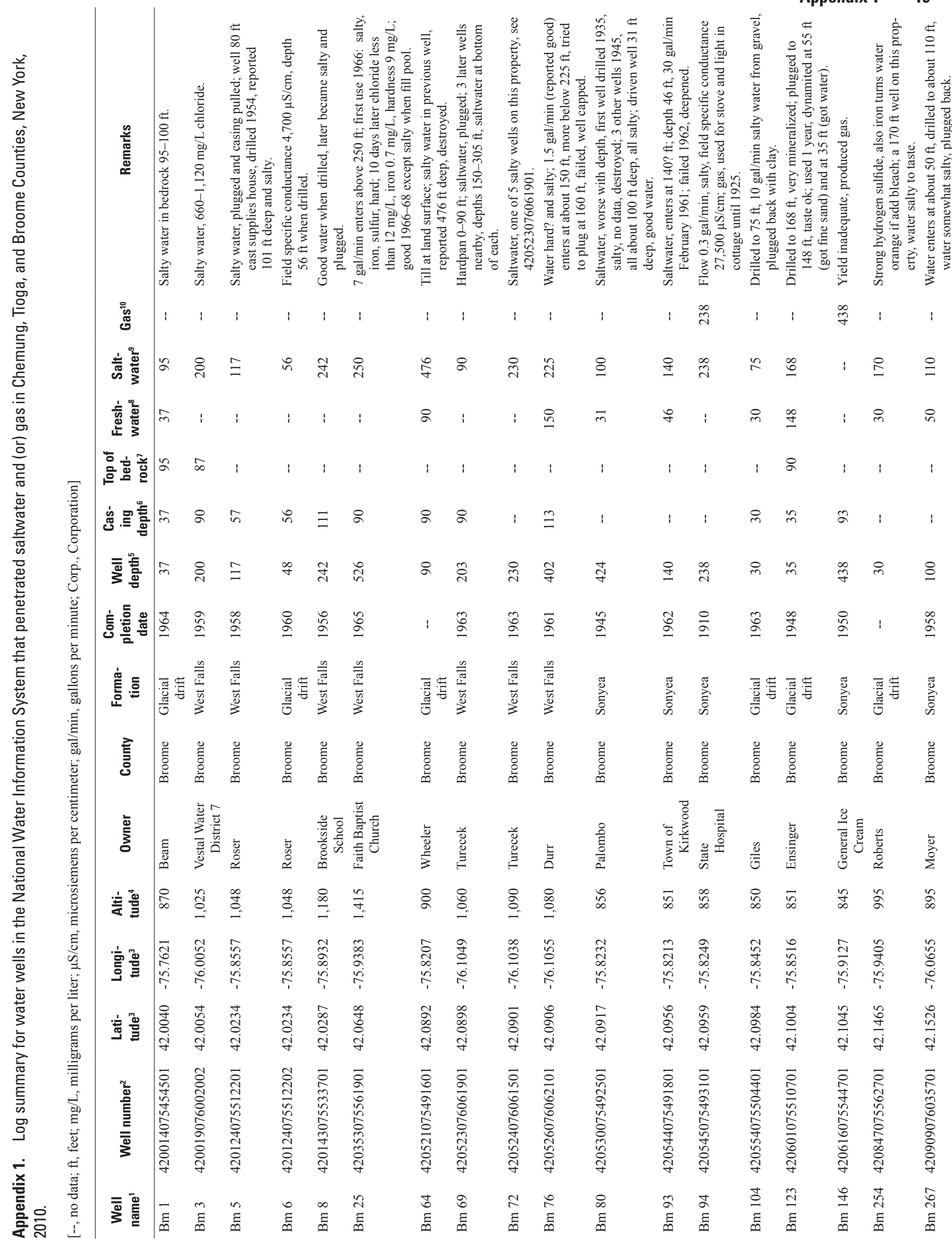




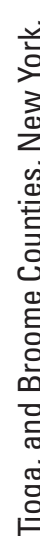
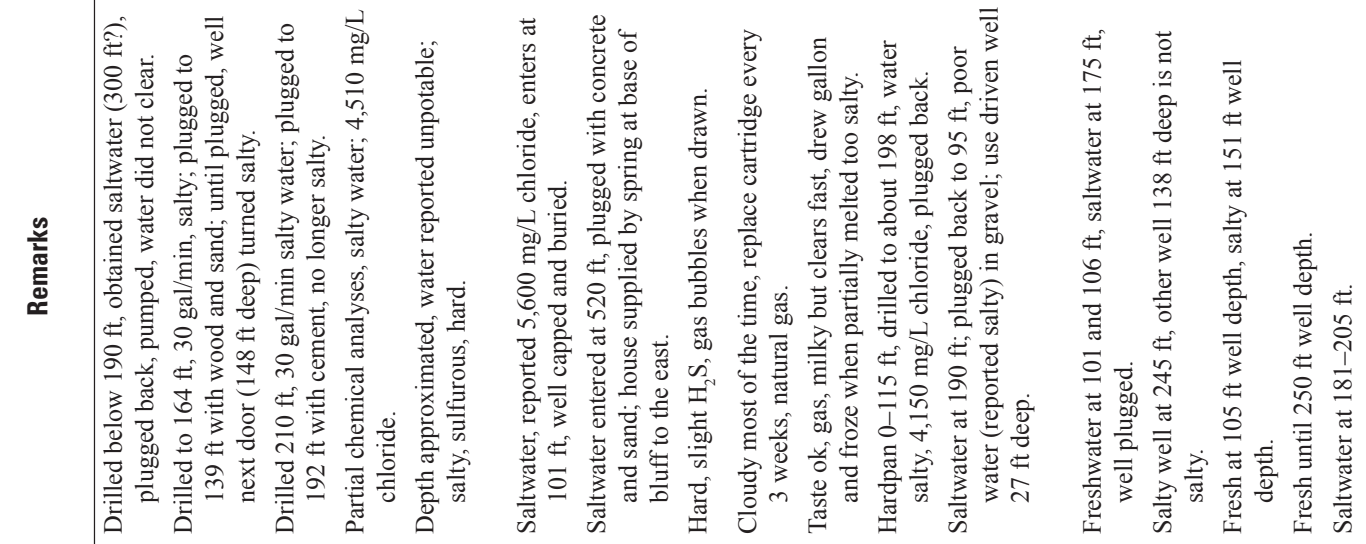

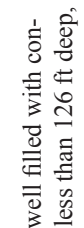

它

今

这离离

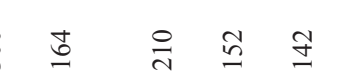

$\stackrel{\text { in }}{\circ}$

๙

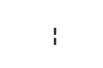

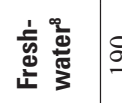

ले న

훙혀원

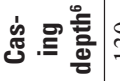

용

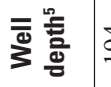

ले

$\approx \cong \cong$

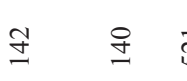

8 요 8 i $\&$

2

$\cong$ 年

言 흔 흠 흥

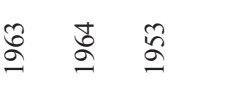

$\stackrel{\infty}{2}$

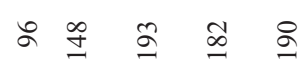

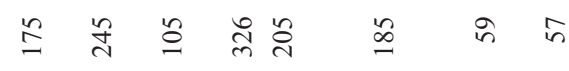

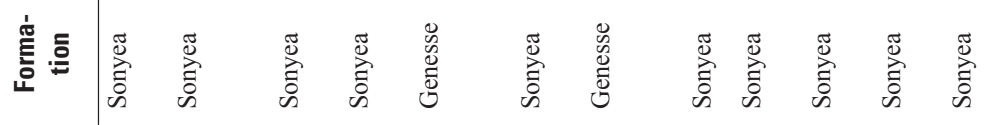

产

ลิ

के

흐 ही

言

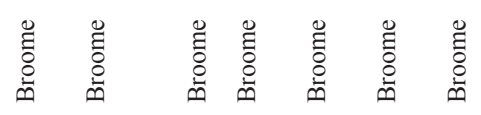

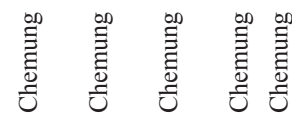

离

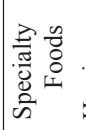

妾离

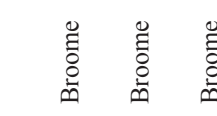

竞

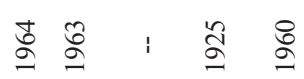

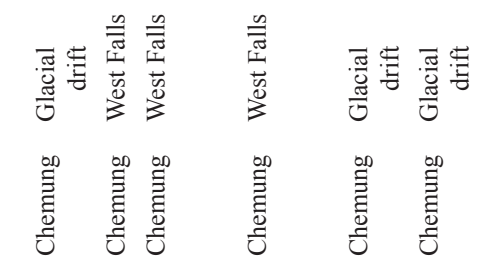

要

ำ

$\stackrel{\oplus}{\stackrel{ \pm}{\leftrightarrows}}$

$\Xi$ हี

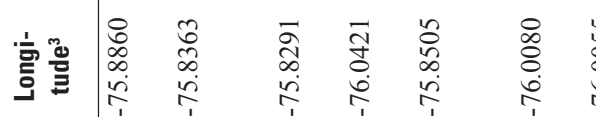

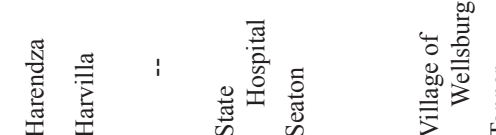

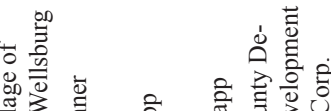

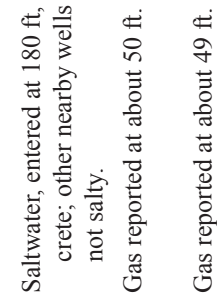

in o 


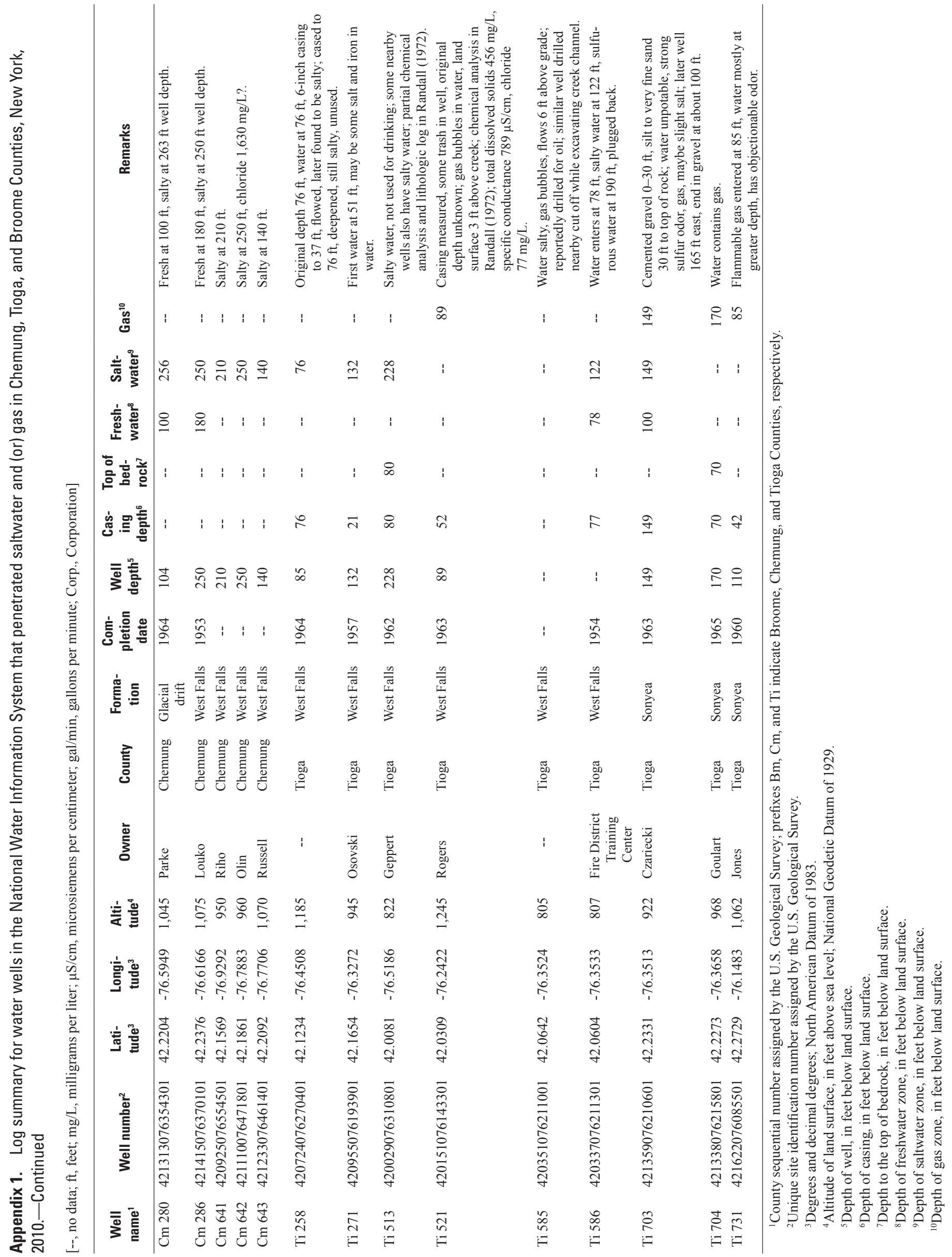


Appendix 2. Log summary for gas wells in the Empire State Oil and Gas System that penetrated freshwater, saltwater and (or) gas above [--, no data; ft, feet; Co., Company; Corp., Corporation; ${ }^{\circ}$ F, degrees Fahrenheit; gal $/$ min, gallons per minute $]$

\begin{tabular}{|c|c|c|c|c|c|c|c|c|c|c|}
\hline Well name & $\begin{array}{l}\text { Well } \\
\text { num- } \\
\text { ber }^{1}\end{array}$ & Latitude $^{2}$ & $\begin{array}{l}\text { Longi- } \\
\text { tude }^{2}\end{array}$ & $\begin{array}{l}\text { Alti- } \\
\text { tude }^{3}\end{array}$ & Owner & County & Formation & $\begin{array}{l}\text { Completion } \\
\text { date }\end{array}$ & $\begin{array}{c}\text { Well } \\
\text { depth }^{4}\end{array}$ & $\begin{array}{l}\text { Surface } \\
\text { casing }^{5}\end{array}$ \\
\hline $\begin{array}{l}\text { Chase Troy } \\
\text { Chem Co. } 1\end{array}$ & 00730 & 42.17580 & -76.02458 & 830 & $\begin{array}{l}\text { National Drilling \& } \\
\text { Development }\end{array}$ & Broome & -- & -- & 4,412 & 1,025 \\
\hline Roger 1 & 01061 & 42.29185 & -75.87700 & 970 & -- & Broome & -- & -- & 2,000 & -- \\
\hline Quarella 1 & 04854 & 42.39907 & -75.88001 & 1,430 & Genegantslet Gas \& Oil Co. & Broome & Medina & $1 / 20 / 1968$ & 5,831 & 598 \\
\hline Gerst 1 & 08342 & 42.39776 & -75.89021 & 1,470 & $\begin{array}{l}\text { James V. Joyce/Dba Pipeline } \\
\text { Co. }\end{array}$ & Broome & Medina & $10 / 2 / 1972$ & 6,420 & 638 \\
\hline V. of Endicott 1 & 21473 & 42.07769 & -76.10143 & 821 & Kidder Exploration, Inc. & Broome & Helderberg & 8/7/1993 & 4,434 & 752 \\
\hline Cirba 01 & 21499 & 42.14089 & -75.84146 & 1,370 & Quaker State Corp. & Broome & Helderberg & $10 / 28 / 1993$ & 5,230 & 717 \\
\hline O’Neil 1 & 21554 & 42.12948 & -75.82361 & 1,325 & Quaker State Corp. & Broome & Helderberg & $10 / 27 / 1994$ & 5,025 & 100 \\
\hline Beagell 01 & 21568 & 42.13628 & -75.83284 & 1,400 & Belden \& Blake Corp. & Broome & Helderberg & $10 / 29 / 1995$ & 5,289 & 718 \\
\hline Pond 1 & 23032 & 42.24375 & -76.04418 & 1,095 & Phillips Production Co. & Broome & Black River & $4 / 23 / 2004$ & 8,990 & 519 \\
\hline Butkowsky 1 & 23056 & 42.14282 & -75.82491 & 1,470 & Belden \& Blake Corp. & Broome & Black River & $10 / 11 / 2003$ & 10,105 & 1,000 \\
\hline Kesselring 1 & 00443 & 42.19864 & -76.53773 & 1,077 & Tremblay, Gail R. \& Alan B. & Chemung & Oriskany & $5 / 6 / 1953$ & 11,145 & -- \\
\hline $\begin{array}{l}\text { Consolidated } \\
\text { Brick Co. } 1\end{array}$ & 00474 & 42.09775 & -76.78581 & 1,002 & Belmont Quadrangle Drilling & Chemung & Oriskany & $3 / 22 / 1940$ & 2,918 & -- \\
\hline English 1 & 00508 & 42.20536 & -76.54253 & 1,286 & NYS Natural Gas Co. & Chemung & Oriskany & $4 / 2 / 1938$ & 3,362 & -- \\
\hline Treat 1 & 00509 & 42.23691 & -76.70516 & 1,659 & Belmont Quadrangle Drilling & Chemung & Oriskany & $12 / 13 / 1938$ & 3,447 & 3,677 \\
\hline Husted & 00510 & 42.22114 & -76.70218 & 1,512 & NYS Natural Gas Co. & Chemung & Oriskany & $9 / 12 / 1939$ & 3,414 & 511 \\
\hline Turner 1 & 00599 & 42.22263 & -76.79994 & 1,087 & Dearth, G. and others & Chemung & -- & $7 / 11 / 1931$ & 3,085 & -- \\
\hline Willis 1 & 00600 & 42.22347 & -76.90397 & 1,277 & Peterman & Chemung & -- & $4 / 20 / 1932$ & 3,135 & -- \\
\hline Gregg 1 & 00601 & 42.09881 & -76.78381 & 1,173 & Belmont Quadrangle Drilling & Chemung & -- & $5 / 2 / 1940$ & 3,129 & -- \\
\hline Shay 1 & 00607 & 42.09133 & -76.79577 & 855 & Rogers and others & Chemung & Oriskany & 9/20/1941 & 2,732 & -- \\
\hline Barcus 1 & 00610 & 42.09390 & -76.78896 & 850 & Kennedy Valve & Chemung & Oriskany & $12 / 10 / 1940$ & 2,712 & 1,506 \\
\hline Barcus 2 & 00611 & 42.09103 & -76.78544 & 843 & $\begin{array}{l}\text { Updegraff, C.H. \& Nichols, } \\
\text { W.M. }\end{array}$ & Chemung & Oriskany & $3 / 28 / 1941$ & 3,306 & -- \\
\hline Harder 1 & 00612 & 42.07076 & -76.82307 & 956 & Rogers and others & Chemung & Oriskany & $1 / 27 / 1941$ & 3,229 & -- \\
\hline Fee 1 & 00613 & 42.09856 & -76.78877 & 858 & Malacoccio & Chemung & Oriskany & $10 / 16 / 1940$ & 2,772 & -- \\
\hline Murphy & 01056 & 42.23553 & -76.88105 & 1,560 & Catlin Oil Gas \& Mineral & Chemung & -- & $3 / 1 / 1903$ & 2,201 & -- \\
\hline Tobey 4 & 01057 & 42.09850 & -76.90786 & 1,100 & Tobey Oil Gas \& Mineral & Chemung & -- & $1 / 1 / 1921$ & 710 & 291 \\
\hline 1_May & 03974 & 42.05185 & -76.88830 & 1,570 & Hanley \& Bird & Chemung & Oriskany & $6 / 18 / 1959$ & 4,319 & 955 \\
\hline City of Elmira 1 & 04001 & 42.10855 & -76.79688 & 866 & Felmont Oil Corp. & Chemung & -- & $8 / 1 / 1960$ & 2,885 & -- \\
\hline Callahan & 04026 & 42.27624 & -76.94501 & 1,637 & Felmont Oil Corp. & Chemung & Oriskany & $7 / 19 / 1960$ & 3,183 & -- \\
\hline Coleman 1 & 04087 & 42.22016 & -76.76962 & 1,115 & Delmont South Penn & Chemung & Oriskany & $5 / 4 / 1961$ & 2,969 & -- \\
\hline
\end{tabular}


the Marcellus Shale in Chemung, Tioga, and Broome Counties, New York, 2010.

\begin{tabular}{|c|c|c|c|c|c|c|c|c|c|}
\hline $\begin{array}{l}\text { Intermediate } \\
\text { casing }^{6}\end{array}$ & $\begin{array}{l}\text { Top of } \\
\text { bed- } \\
\text { rock }^{7}\end{array}$ & $\begin{array}{l}\text { Top of } \\
\text { Tully }\end{array}$ & $\begin{array}{l}\text { Top of } \\
\text { Mar- } \\
\text { cellus }^{9}\end{array}$ & $\begin{array}{l}\text { Fresh } \\
\text { water }^{10}\end{array}$ & $\begin{array}{c}\text { Salt } \\
\text { water Up } \\
\text { Dev }^{11}\end{array}$ & $\begin{array}{c}\text { Salt } \\
\text { water } \\
\text { Tully }^{12}\end{array}$ & Gas Up Dev ${ }^{13}$ & $\begin{array}{l}\text { Gas } \\
\text { Tully }{ }^{14}\end{array}$ & Remarks \\
\hline-- & -- & 2,250 & -- & -- & 850 & -- & -- & -- & $850-1,025 \mathrm{ft}$ sand and much saltwater. \\
\hline-- & -- & -- & -- & -- & -- & -- & 2,000 & -- & Salt spring or $30 \mathrm{ft}$ salt well $1 / 4 \mathrm{mi}$ away. \\
\hline-- & -- & 1,440 & -- & 100 & -- & -- & 867 & -- & Freshwater at $100 \mathrm{ft}$, strong gas show at $867 \mathrm{ft}$. \\
\hline-- & -- & 1,487 & -- & $\begin{array}{l}125,317 \\
595\end{array}$ & 920 & -- & $858,920,1,250$ & -- & $\begin{array}{l}\text { Freshwater at } 125,317 \text {, and } 595 \mathrm{ft} \text {; saltwater at } 920 \mathrm{ft} \text {; gas } \\
\text { at } 858,920 \text {, and } 1,250 \mathrm{ft} \text {. }\end{array}$ \\
\hline-- & -- & 2,666 & -- & -- & -- & -- & -- & -- & $\begin{array}{l}\text { Gas shows in upper Devonian and Hamilton (depths not } \\
\text { specified). }\end{array}$ \\
\hline-- & 125 & 2,336 & -- & -- & -- & -- & -- & -- & Gas shows in upper Devonian (depths not specified). \\
\hline-- & -- & 2,635 & & 78 & -- & -- & -- & -- & Shale at $0 \mathrm{ft}, 1 / 2$ inch stream at $78 \mathrm{ft}$. \\
\hline 700 & 30 & 2,704 & -- & 138 & -- & 3,400 & -- & -- & Shale at $30 \mathrm{ft}, 1 / 4$ inch stream at $138 \mathrm{ft}$, brine at $3,400 \mathrm{ft}$. \\
\hline-- & -- & 2,677 & -- & 88 & -- & -- & -- & -- & $1 / 2$ inch stream at $88 \mathrm{ft}$ freshwater. \\
\hline-- & 42 & 2,600 & -- & 50,100 & -- & -- & -- & -- & Shale at $42 \mathrm{ft}$, water $1 / 4$ inch at $50 \mathrm{ft}, 1$ inch at $100 \mathrm{ft}$. \\
\hline-- & 57 & 2,228 & 4,113 & 57,85 & -- & -- & -- & -- & $\begin{array}{l}\text { Freshwater } 12 \mathrm{gal} / \mathrm{min} \text { in gravel at } 57 \mathrm{ft} \text {, shale at } 57 \mathrm{ft} \text {, damp } \\
\text { at } 85 \mathrm{ft} \text {. }\end{array}$ \\
\hline-- & 69 & 2,608 & 4,512 & 145,370 & -- & -- & -- & -- & $\begin{array}{l}0-69 \mathrm{ft} \text { gravel, sand, and silt; shale at } 69 \mathrm{ft} \text {, damp in shale at } \\
145 \mathrm{ft} \text {, freshwater at } 370 \mathrm{ft} \text {. }\end{array}$ \\
\hline 2,509 & -- & 2,348 & -- & 590,736 & -- & -- & -- & -- & Show freshwater at 590 and $736 \mathrm{ft}$. \\
\hline $7,200(4,500)$ & -- & 2,707 & -- & 200 & -- & -- & -- & -- & $\begin{array}{l}\text { Freshwater at } 200 \mathrm{ft} \text {, conductor casing set to } 40 \mathrm{ft} \text {, have } \\
\text { wrong PDF file (W65 St A). }\end{array}$ \\
\hline-- & 54 & 1,620 & 2,770 & -- & -- & -- & $713,868,908$ & -- & $\begin{array}{l}\text { Large volume saltwater in Thersea, } 5,000 \mathrm{ft} \text { saltwater at TD, } \\
\text { deepest cable tool hole in the world, bottom hole temp, } \\
245^{\circ} \mathrm{F} \text {. }\end{array}$ \\
\hline-- & -- & 1,616 & -- & -- & -- & -- & -- & 1,704 & \\
\hline-- & 0 & 1,834 & 3,118 & -- & 1,019 & -- & 1,035 & -- & \\
\hline-- & -- & 2,125 & -- & -- & -- & -- & -- & -- & Saltwater at 3,444 ft well filled up to $100 \mathrm{ft}$ in 30 hours. \\
\hline-- & 27 & 2,065 & 3,187 & 115 & -- & -- & -- & -- & 15 to $20 \mathrm{gal} / \mathrm{min}$ at $114-116 \mathrm{ft}, 0-27 \mathrm{ft}$ glacial drift. \\
\hline-- & 10 & 2,130 & -- & 55 & -- & -- & -- & -- & Water at $55 \mathrm{ft}$ in shale. \\
\hline-- & -- & 1,474 & -- & -- & -- & -- & -- & -- & $\begin{array}{l}50 \text { MCF shale gas at } 2,310-2,525 \mathrm{ft}, 260-88 \mathrm{MCF} \text { with } \\
6 \text { barrels saltwater in black shale. }\end{array}$ \\
\hline-- & -- & 1,773 & -- & -- & 1,235 & -- & -- & -- & $800 \mathrm{ft}$ of saltwater at $1,235 \mathrm{ft}$. \\
\hline-- & -- & 1,528 & -- & 700 & -- & -- & -- & -- & $\begin{array}{l}700-701 \mathrm{ft} \mathrm{gravel} \mathrm{below} 640 \mathrm{ft} \text { of clay, flowed at } \\
3,580 \mathrm{gal} / \mathrm{min} \text { for } 4 \text { days, spurted up } 8 \mathrm{ft} \text { in air from } \\
10 \text { inch casing. }\end{array}$ \\
\hline-- & -- & 1,518 & -- & -- & -- & -- & -- & -- & $\begin{array}{l}\text { Well abandoned in Tully limestone, well apparently in path } \\
\text { of fault. }\end{array}$ \\
\hline-- & 40 & 1,560 & 2,675 & -- & -- & -- & $1,425,1,560$ & -- & $\begin{array}{l}\text { Fault well? } 800 \mathrm{MCF} \text { at } 1,425-1,560 \mathrm{ft} \text { exhausted in } \\
10 \text { days. Sulphur gas } 95-115 \mathrm{ft} \text { and } 340-347 \mathrm{ft} \text {. }\end{array}$ \\
\hline-- & 42 & 1,990 & 2,980 & -- & -- & -- & $350-450$ & -- & Small gas flow between $350-450 \mathrm{ft}$. \\
\hline-- & -- & 1,845 & -- & -- & -- & -- & -- & 1,928 & \\
\hline-- & -- & 1,461 & -- & -- & 500 & -- & -- & -- & Well on knee of fault, $500 \mathrm{ft}$ saltwater 2 inch stream. \\
\hline-- & -- & 1,455 & -- & -- & 1,434 & 1,455 & 1,434 & 1,455 & $350 \mathrm{MCF}$ in Tully and hole full of saltwater. \\
\hline-- & -- & 1,450 & -- & -- & -- & -- & -- & 1,450 & $50 \mathrm{MCF}$ in Tully. \\
\hline-- & 70 & 1,980 & -- & 125,325 & -- & -- & -- & 1,980 & $\begin{array}{l}0-70 \mathrm{ft} \text { clay and gravel, little water at } 125 \mathrm{ft} \text {, lots of water at } \\
325 \mathrm{ft} ; 75 \text { MCF in Tully. }\end{array}$ \\
\hline-- & -- & 1,470 & -- & -- & -- & -- & -- & 1,470 & 75 MCF in Tully. \\
\hline-- & 17 & 1,764 & -- & -- & 1,265 & -- & 1,718 & -- & Saltwater at $1,718 \mathrm{ft}$, gas at $1,265 \mathrm{ft}$ and some oil at $1,763 \mathrm{ft}$. \\
\hline-- & -- & -- & -- & -- & -- & -- & 610,645 & -- & \\
\hline-- & -- & 3,125 & 4,110 & -- & -- & -- & $1,290,1,334$ & -- & Show of gas at $1,290-1,334 \mathrm{ft}$. \\
\hline-- & -- & 1,595 & -- & -- & -- & -- & -- & 1,595 & $3 \mathrm{MCF}$ in Tully. \\
\hline-- & -- & 1,990 & 3,002 & -- & 1,780 & -- & 1,205 & -- & $\begin{array}{l}\text { Show of gas at } 1,205 \mathrm{ft} \text { blew down to nothing by time well } \\
\text { got to } 1,311 \mathrm{ft}, 15 \text { gallons saltwater overnight at } 1,780 \mathrm{ft} \text {. }\end{array}$ \\
\hline-- & -- & 1,552 & 2,635 & -- & -- & -- & 1,416 & -- & Gas pocket $1,416-1,426 \mathrm{ft}$. \\
\hline
\end{tabular}


Appendix 2. Log summary for gas wells in the Empire State Oil and Gas System that penetrated freshwater, saltwater and (or) gas above [--, no data; ft, feet; Co., Company; Corp, Corporation; ${ }^{\circ}$, degrees Fahrenheit; gal/min, gallons per minute]

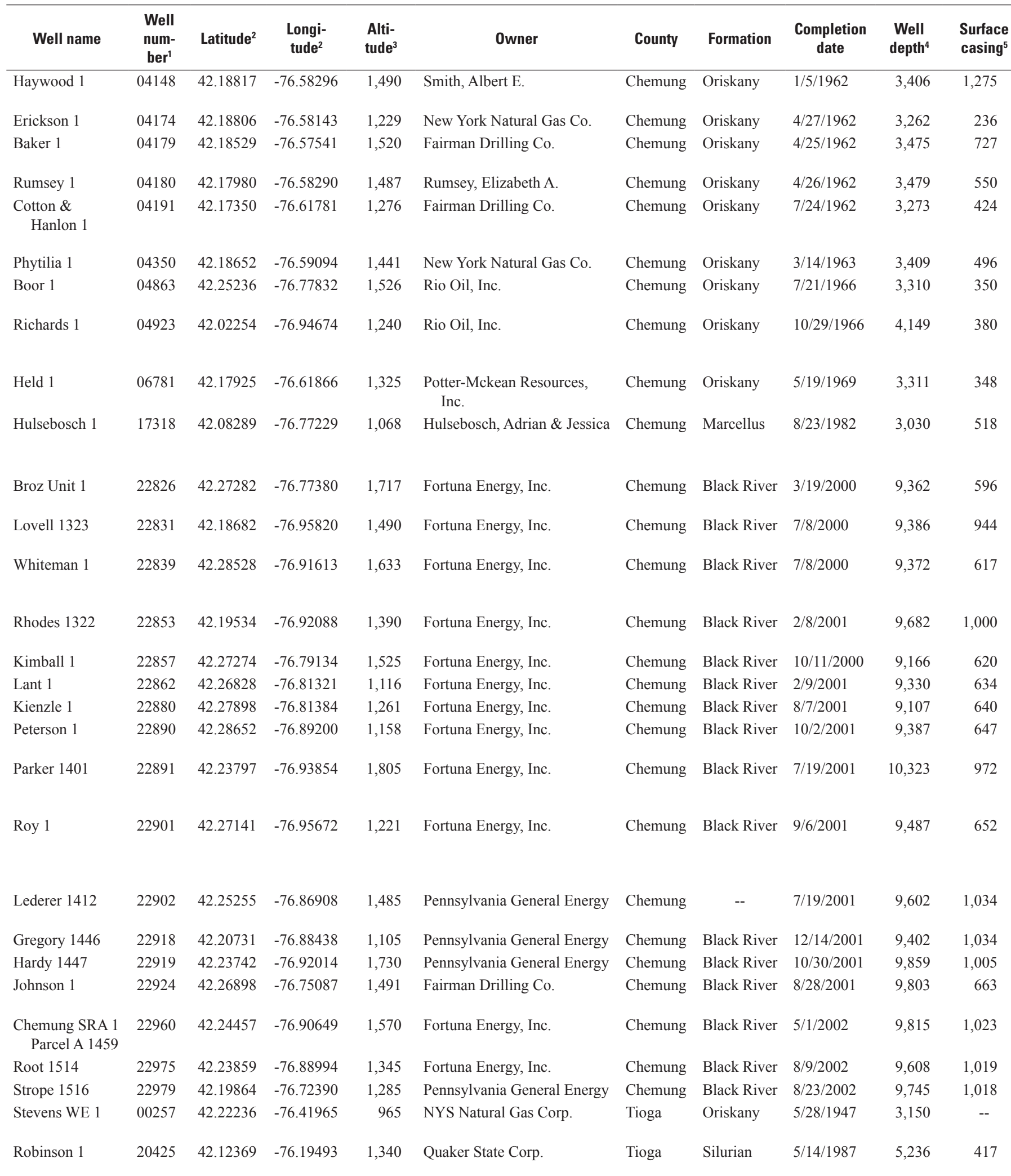


the Marcellus Shale in Chemung, Tioga, and Broome Counties, New York, 2010.-Continued

\begin{tabular}{|c|c|c|c|c|c|c|c|c|c|}
\hline $\begin{array}{l}\text { Intermediate } \\
\text { casing }^{6}\end{array}$ & $\begin{array}{l}\text { Top of } \\
\text { bed- } \\
\text { rock }^{7}\end{array}$ & $\begin{array}{l}\text { Top of } \\
\text { Tully }^{8}\end{array}$ & $\begin{array}{l}\text { Top of } \\
\text { Mar- } \\
\text { cellus }^{9}\end{array}$ & $\begin{array}{l}\text { Fresh } \\
\text { water }^{10}\end{array}$ & $\begin{array}{l}\text { Salt } \\
\text { water Up } \\
\text { Dev }^{11}\end{array}$ & $\begin{array}{c}\text { Salt } \\
\text { water } \\
\text { Tully }\end{array}$ & Gas Up Dev ${ }^{13}$ & $\begin{array}{l}\text { Gas } \\
\text { Tully }^{14}\end{array}$ & Remarks \\
\hline-- & -- & 2,036 & 3,134 & $84,120,420$ & -- & -- & -- & -- & $\begin{array}{l}\text { Freshwater at } 84 \mathrm{ft} \text {, not enough to drill with, } 120 \mathrm{ft} \text { hole full, } \\
\text { hole full at } 420 \mathrm{ft} \text {. }\end{array}$ \\
\hline-- & -- & 1,795 & -- & 189 & -- & -- & 730 & -- & No saltwater before Oriskany, gas show at $730 \mathrm{ft}$. \\
\hline-- & -- & 2,093 & -- & 75,155 & -- & -- & 1,100 & -- & $\begin{array}{l}\text { Freshwater at } 75 \text { and } 155 \mathrm{ft} \text { in sandstone and shale, gas } \\
\text { show } 1,100-1,119 \mathrm{ft} .\end{array}$ \\
\hline-- & -- & 2,091 & -- & 25,137 & -- & -- & -- & -- & Freshwater at $25 \mathrm{ft}$, hole full of water at $137 \mathrm{ft}$. \\
\hline-- & 40 & 1,857 & -- & 100 & 1,178 & -- & $\begin{array}{l}360,560,950 \\
\quad 1,178\end{array}$ & -- & $\begin{array}{l}0-40 \mathrm{ft} \text { overburden, bailing freshwater at } 100 \mathrm{ft}, 5 \mathrm{gal} / \text { hour } \\
\text { saltwater at } 1,178 \mathrm{ft} \text {, gas shows at } 360,560,950 \text {, and } \\
1,178 \mathrm{ft} \text {. }\end{array}$ \\
\hline-- & -- & 2,017 & 3,110 & 85 & -- & -- & -- & 2,281 & Freshwater at $85 \mathrm{ft}, 52 \mathrm{MCF}$ gas at $2,281-2,285 \mathrm{ft}$. \\
\hline-- & 34 & 2,033 & 3,060 & 80 & -- & -- & 1,177 & 2,049 & $\begin{array}{l}0-34 \mathrm{ft} \text { sand, clay, and gravel, good flow freshwater at } 80 \mathrm{ft} \\
\text { in shale, oil shows } 550 \text { and 2,049 ft. }\end{array}$ \\
\hline-- & 75 & 2,964 & 3,908 & 75,88 & 549,956 & -- & 623 & -- & $\begin{array}{l}0-75 \mathrm{ft} \text { sand, gravel, and boulders, freshwater in gravel, } \\
\text { freshwater at } 88 \mathrm{ft} \text { in sandstone, saltwater at } 549 \text { and } \\
956 \mathrm{ft} \text {, gas show less than } 20 \mathrm{MCF} \text { at } 623 \mathrm{ft} .\end{array}$ \\
\hline-- & 75 & 1,910 & 3,057 & 101 & -- & -- & -- & -- & Overburden 0-75 ft. \\
\hline-- & 80 & 1,770 & 2,875 & 77 & 1,350 & -- & $\begin{array}{c}1,180,1,285 \\
1,454,1,502 \\
1,563,1,612\end{array}$ & -- & $\begin{array}{l}\text { Water in gravel at } 77 \mathrm{ft} \text {, silty shale at } 80 \mathrm{ft} \text {, perforated } \\
2,900-2,960 \mathrm{ft} \text { in Marcellus. }\end{array}$ \\
\hline $5,680(4,833)$ & 15 & 2,391 & -- & 105 & -- & -- & -- & -- & $\begin{array}{l}0-15 \mathrm{ft} \text { clay, } 2 \text { inch stream freshwater at } 105 \mathrm{ft} \text { in sandstone } \\
\text { and shale. }\end{array}$ \\
\hline 6,662 & 89 & 2,412 & -- & 240 & -- & -- & -- & -- & $\begin{array}{l}15-89 \mathrm{ft} \text { clay and gravel, } 4 \text { inch stream of freshwater at } \\
240 \mathrm{ft} \text { in sandstone and shale. }\end{array}$ \\
\hline $5,618(3,352)$ & 26 & 1,822 & 2,832 & 25,58 & -- & -- & -- & -- & $\begin{array}{l}1 / 2 \text { inch stream freshwater at } 25 \mathrm{ft} \text { in unconsolidated, } \\
2 \text { inch stream freshwater at } 58 \mathrm{ft} \text { in shale, shale } \\
26-405 \mathrm{ft} \text {, sandstone and shale } 405-620 \mathrm{ft} \text {. }\end{array}$ \\
\hline $5,929(2,000)$ & 6 & 2,256 & -- & 328,784 & -- & -- & -- & -- & $\begin{array}{l}0-6 \mathrm{ft} \mathrm{fill}, 1 \text { inch stream of freshwater at } 328 \mathrm{ft} \text { in sandstone, } \\
11 / 2 \text { inchstream of freshwater at } 784 \mathrm{ft} \text { in shale. }\end{array}$ \\
\hline 5,570 & -- & 2,153 & -- & 71 & -- & -- & -- & -- & 2 inch stream freshwater at $71 \mathrm{ft}$ in gravel. \\
\hline $5,176(2,090)$ & -- & 1,792 & 2,855 & 50 & -- & -- & -- & -- & Sandstone at $28 \mathrm{ft}, 1 / 2$ inch freshwater at $50 \mathrm{ft}$ in sandstone. \\
\hline $5,874(2,320)$ & 28 & 1,916 & 2,973 & 60 & -- & -- & -- & -- & $0-195 \mathrm{ft}$ shale, $3 \mathrm{ft}$ fresh at $60 \mathrm{ft}$. \\
\hline $5,142(2,510)$ & 0 & 1,487 & 2,510 & 22,74 & -- & -- & -- & -- & $\begin{array}{l}1 \text { inch freshwater stream at } 22 \mathrm{ft}, 4 \text { inch stream freshwater at } \\
74 \mathrm{ft} \text { in gravel, base of gravel at } 94 \mathrm{ft} \text {. }\end{array}$ \\
\hline $6,157(3,400)$ & 4 & 2,696 & -- & $30,135,480$ & -- & -- & -- & -- & $\begin{array}{l}\text { Sandstone and shale } 4-2,696 \mathrm{ft}, 1 / 4 \text { inch stream freshwater } \\
\text { at } 30 \mathrm{ft}, 1 \text { inch stream at } 135 \mathrm{ft} \text { and } 1 \text { inch stream at } \\
480 \mathrm{ft} \text {. }\end{array}$ \\
\hline $5,893(3,200)$ & 77 & 1,684 & 2,659 & $\begin{array}{l}24,47,83 \\
\quad 114,120 \\
203\end{array}$ & 1,190 & -- & -- & -- & $\begin{array}{l}23-77 \mathrm{ft} \text { gravel, } 77-1,684 \mathrm{ft} \text { shale, damp at } 23 \mathrm{ft}, 2 \text { inch } \\
\text { fresh at } 24 \mathrm{ft} \text { and } 3 \text { inch fresh at } 47 \mathrm{ft}, 2 \text { inch fresh at } \\
83 \mathrm{ft}, 3 \text { inch fresh at } 114 \mathrm{ft}, 4 \text { inch fresh at } 120 \mathrm{ft}, 3 \text { inch } \\
\text { fresh at } 203 \mathrm{ft} \text {, damp at } 1,190 \mathrm{ft} .\end{array}$ \\
\hline 5,735 & 15 & 2,260 & -- & 114,203 & -- & -- & -- & -- & $\begin{array}{l}\text { Shale and sandstone at } 15 \mathrm{ft} \text {, damp at } 114 \mathrm{ft} \text { and } 1 \text { inch } \\
\text { stream at } 203 \mathrm{ft} \text {. }\end{array}$ \\
\hline $6,360(2,700)$ & -- & 1,802 & -- & 84 & -- & -- & -- & -- & $1 / 2$ inch stream of freshwater at $84 \mathrm{ft}$. \\
\hline $6,102(3,500)$ & 95 & 2,608 & -- & 75 & -- & -- & -- & -- & $20-95 \mathrm{ft}$ sand and gravel, $1 / 2 \mathrm{ft}$ stream freshwater at $75 \mathrm{ft}$. \\
\hline $6,130(3,540)$ & 134 & 2,082 & 3,163 & $28,133,195$ & -- & -- & -- & -- & $\begin{array}{l}18-134 \mathrm{ft} \text { clay and gravel, } 1 \text { inch fresh at } 28 \mathrm{ft} \text { and fresh at } \\
133 \mathrm{ft} \text {, shale at } 134 \mathrm{ft}, 1 \text { inch fresh at } 195 \mathrm{ft} .\end{array}$ \\
\hline $5,935(3,200)$ & 21 & 2,412 & -- & 85 & -- & -- & -- & -- & Shale at $21 \mathrm{ft}, 2$ inch stream freshwater at $85 \mathrm{ft}$. \\
\hline $5,700(3,000)$ & 40 & 2,125 & -- & 210 & -- & -- & -- & -- & Shale at $40 \mathrm{ft}, 11 / 2$ inch stream freshwater at $210 \mathrm{ft}$. \\
\hline $5,890(2,875)$ & 98 & 1,838 & -- & 85 & -- & -- & -- & -- & 2 inch stream in gravel at $85 \mathrm{ft}$, shale at $98 \mathrm{ft}$. \\
\hline-- & 70 & 1,542 & -- & 12,130 & -- & -- & 263,270 & -- & $\begin{array}{l}0-70 \mathrm{ft} \text { gravel, freshwater in gravel at } 12 \mathrm{ft} \text { and in shale at } \\
130 \mathrm{ft} \text {, gas shows at } 263 \text { and } 270 \mathrm{ft} .\end{array}$ \\
\hline $1,164(932)$ & 28 & 2,870 & 4,461 & 28,105 & -- & -- & -- & -- & $\begin{array}{l}\text { Freshwater in gravel at } 28 \mathrm{ft}(1 / 4 \mathrm{inch}) \text { and in shale at } \\
105 \mathrm{ft}(1 \text { inch). }\end{array}$ \\
\hline
\end{tabular}


Appendix 2. Log summary for gas wells in the Empire State Oil and Gas System that penetrated freshwater, saltwater and (or) gas above $\left[--\right.$, no data; ft, feet; Co., Company; Corp, Corporation; ${ }^{\circ} \mathrm{F}$, degrees Fahrenheit; gal $/ \mathrm{min}$, gallons per minute $]$

\begin{tabular}{|c|c|c|c|c|c|c|c|c|c|c|}
\hline Well name & $\begin{array}{c}\text { Well } \\
\text { num- } \\
\text { ber }^{1}\end{array}$ & Latitude $^{2}$ & $\begin{array}{l}\text { Longi- } \\
\text { tude }^{2}\end{array}$ & $\begin{array}{l}\text { Alti- } \\
\text { tude }^{3}\end{array}$ & Owner & County & Formation & $\begin{array}{l}\text { Completion } \\
\text { date }\end{array}$ & $\begin{array}{l}\text { Well } \\
\text { depth }^{4}\end{array}$ & $\begin{array}{l}\text { Surface } \\
\text { casing }^{5}\end{array}$ \\
\hline Fyock 1 & 20427 & 42.03624 & -76.21665 & 1,265 & $\begin{array}{l}\text { Central New York Oil \& Gas } \\
\text { Co., LLC }\end{array}$ & Tioga & Helderberg & $2 / 27 / 1987$ & 5,534 & 116 \\
\hline Racht 1 & 20531 & 42.03360 & -76.22227 & 1,485 & $\begin{array}{l}\text { Central New York Oil \& Gas } \\
\text { Co., LLC }\end{array}$ & Tioga & Helderberg & $10 / 14 / 1987$ & 5,410 & 966 \\
\hline Torbert 1 & 20532 & 42.05656 & -76.24139 & 1,260 & Quaker State Corp. & Tioga & Helderberg & $10 / 28 / 1987$ & 5,154 & 994 \\
\hline Hakes 1 & 20534 & 42.02248 & -76.22789 & 1,470 & Quaker State Corp. & Tioga & Helderberg & $10 / 20 / 1987$ & 5,484 & 1,003 \\
\hline Barnhart 1 & 20644 & 42.02530 & -76.25499 & 1,480 & $\begin{array}{l}\text { Central New York Oil \& Gas } \\
\text { Co., LLC }\end{array}$ & Tioga & Helderberg & $11 / 15 / 1988$ & 5,232 & 519 \\
\hline Mead 1 & 20645 & 42.03417 & -76.19666 & 1,400 & Quaker State Corp. & Tioga & Helderberg & $12 / 29 / 1988$ & 5,225 & 873 \\
\hline Owen 01 & 21264 & 42.02386 & -76.27509 & 1,580 & $\begin{array}{l}\text { Central New York Oil \& Gas } \\
\text { Co., LLC }\end{array}$ & Tioga & Onondaga & $8 / 29 / 1989$ & 5,375 & 751 \\
\hline Owen 02 & 21265 & 42.03197 & -76.27519 & 1,440 & Quaker State Corp. & Tioga & -- & 9/4/1989 & 5,295 & 686 \\
\hline Cook 01 & 21272 & 42.01059 & -76.29758 & 1,600 & $\begin{array}{l}\text { Central New York Oil \& Gas } \\
\text { Co., LLC }\end{array}$ & Tioga & Helderberg & $12 / 13 / 2006$ & 5,455 & 722 \\
\hline Mead 01 & 21294 & 42.01176 & -76.27324 & 1,430 & EOG Resources, Inc. & Tioga & Helderberg & 9/5/1990 & 5,268 & 721 \\
\hline Widell 01 & 21300 & 42.04916 & -76.19729 & 1,150 & $\begin{array}{l}\text { Central New York Oil \& Gas } \\
\text { Co., LLC }\end{array}$ & Tioga & Helderberg & $6 / 26 / 1990$ & 4,720 & 511 \\
\hline Kittle 1 & 21375 & 42.01327 & -76.31344 & 1,185 & Quaker State Corp. & Tioga & Silurian & $10 / 31 / 1990$ & 5,597 & 532 \\
\hline Spencer 1 & 21378 & 42.21514 & -76.45367 & 1,100 & Fault Line Oil Corp. & Tioga & Silurian & $6 / 24 / 1993$ & 3,246 & 336 \\
\hline Lacher 01 & 21394 & 42.00386 & -76.31213 & 1,475 & $\begin{array}{l}\text { Central New York Oil \& Gas } \\
\text { Co., LLC }\end{array}$ & Tioga & Helderberg & $12 / 6 / 2006$ & 5,293 & 698 \\
\hline Jones 01 & 21420 & 42.05012 & -76.17812 & 1,035 & $\begin{array}{l}\text { Central New York Oil \& Gas } \\
\text { Co., LLC }\end{array}$ & Tioga & Helderberg & 8/6/1991 & 4,634 & 711 \\
\hline Brenchley 01 & 21421 & 42.01080 & -76.28504 & 1,435 & $\begin{array}{l}\text { Central New York Oil \& Gas } \\
\text { Co., LLC }\end{array}$ & Tioga & Helderberg & $6 / 27 / 2006$ & 5,203 & 708 \\
\hline Campbell 01 & 21424 & 42.04242 & -76.20872 & 1,355 & $\begin{array}{l}\text { Central New York Oil \& Gas } \\
\text { Co., LLC }\end{array}$ & Tioga & Helderberg & $5 / 21 / 2003$ & 5,031 & 714 \\
\hline Pierce 01 & 21451 & 42.04978 & -76.15903 & 1,140 & $\begin{array}{l}\text { Central New York Oil \& Gas } \\
\text { Co., LLC }\end{array}$ & Tioga & Helderberg & 9/2/1992 & 4,823 & 709 \\
\hline Bell 01 & 21452 & 42.05535 & -76.18144 & 1,180 & Quaker State Corp. & Tioga & Helderberg & $3 / 12 / 1993$ & 4,675 & 699 \\
\hline Pierce 02 & 21462 & 42.05535 & -76.16042 & 975 & Quaker State Corp. & Tioga & Oriskany & 9/13/1994 & 4,585 & 715 \\
\hline Meade 02 & 21497 & 42.01795 & -76.27435 & 1,450 & Quaker State Corp. & Tioga & Helderberg & $9 / 11 / 1993$ & 5,338 & 770 \\
\hline Faber 01 & 21547 & 42.02895 & -76.25518 & 1,510 & Quaker State Corp. & Tioga & Helderberg & $8 / 27 / 1994$ & 5,435 & 713 \\
\hline Wiggins 1 & 21552 & 42.03321 & -76.23840 & 1,335 & Quaker State Corp. & Tioga & Helderberg & 9/20/1994 & 5,130 & 738 \\
\hline Waite 1 & 21708 & 42.00234 & -76.30054 & 1,400 & EOG Resources, Inc. & Tioga & Oriskany & $1 / 22 / 1998$ & 5,264 & 776 \\
\hline Nichols-Mead 1 & 21709 & 42.00275 & -76.32391 & 1,225 & $\begin{array}{l}\text { Central New York Oil \& Gas } \\
\text { Co., LLC }\end{array}$ & Tioga & Helderberg & $12 / 20 / 2006$ & 4,928 & 775 \\
\hline
\end{tabular}

${ }^{1}$ American Petroleum Institute unique well identifier assigned by the New York State Department of Environmental Conservation, Division of Mineral Resources.

${ }^{2}$ Degrees and decimal degrees; North American Datum of 1983.

${ }^{3}$ Altitude of land surface, in feet above sea level.

${ }^{4}$ Depth of well, in feet below land surface.

${ }^{5}$ Depth of surface casing cemented to land surface, in feet below land surface.

${ }^{6}$ Depth of intermediate casing, in feet below land surface; top of intermediate casing cement, in feet below land surface, in parentheses.

${ }^{7}$ Depth to the top of bedrock, in feet below land surface.

${ }^{8}$ Depth to the top of the Tully Limestone, in feet below land surface.

${ }^{9}$ Depth to the top of the Marcellus Shale, in feet below land surface.

${ }^{10}$ Depth of freshwater zone(s), in feet below land surface.

${ }^{11}$ Depth of saltwater zone(s) in Upper Devonian bedrock, in feet below land surface.

${ }^{12}$ Depth of saltwater zone(s) in the Tully Limestone and Hamilton Group above the Marcellus Shale, in feet below land surface.

${ }^{13}$ Depth of gas zone(s) in Upper Devonian bedrock, in feet below land surface.

${ }^{14}$ Depth of gas zone(s) in the Tully Limestone and Hamilton Group above the Marcellus Shale, in feet below land surface. 
the Marcellus Shale in Chemung, Tioga, and Broome Counties, New York, 2010.-Continued

\begin{tabular}{|c|c|c|c|c|c|c|c|c|c|}
\hline $\begin{array}{l}\text { Intermediate } \\
\text { casing }^{6}\end{array}$ & $\begin{array}{l}\text { Top of } \\
\text { bed- } \\
\text { rock }^{7}\end{array}$ & $\begin{array}{l}\text { Top of } \\
\text { Tully }\end{array}$ & $\begin{array}{l}\text { Top of } \\
\text { Mar- } \\
\text { cellus }^{9}\end{array}$ & $\begin{array}{l}\text { Fresh } \\
\text { water }^{10}\end{array}$ & $\begin{array}{l}\text { Salt } \\
\text { water Up } \\
\text { Dev }^{11}\end{array}$ & $\begin{array}{c}\text { Salt } \\
\text { water } \\
\text { Tully }^{12}\end{array}$ & Gas Up Dev ${ }^{13}$ & $\begin{array}{l}\text { Gas } \\
\text { Tully }^{14}\end{array}$ & Remarks \\
\hline $1,176(944)$ & 20 & 2,865 & 4,548 & $\begin{array}{l}31,60,80 \\
650\end{array}$ & -- & -- & -- & -- & $\begin{array}{l}\text { Freshwater in shale at } 31 \mathrm{ft}(1 / 2 \text { inch }), 60 \mathrm{ft}(1 \mathrm{inch}) \text {, and } \\
80 \mathrm{ft}(2 \text { inch }) ; 1 \text { inch stream at } 650 \mathrm{ft} .\end{array}$ \\
\hline-- & 10 & 3,100 & 4,700 & 22 & -- & -- & -- & -- & Freshwater at $22 \mathrm{ft}$ in shale. \\
\hline-- & 0 & 2,830 & 4,410 & 60 & -- & -- & -- & -- & Freshwater at $60 \mathrm{ft}$ in shale. \\
\hline-- & 10 & 3,110 & 4,718 & $\begin{array}{l}18,65,95 \\
140\end{array}$ & -- & -- & -- & -- & Freshwater at $18,65,95$, and $140 \mathrm{ft}$ in shale. \\
\hline-- & -- & 3,188 & 4,781 & 97,300 & -- & -- & -- & -- & $1 / 2$ inch stream at $97 \mathrm{ft}$ and 2 inch stream at $300 \mathrm{ft}$. \\
\hline-- & -- & 2,975 & 4,625 & 65,523 & -- & 2,995 & -- & -- & $\begin{array}{l}1 / 2 \text { inch at } 65 \mathrm{ft} \text { and } 11 / 2 \text { inch at } 523 \mathrm{ft} \text {, hit water at } \\
2,995 \mathrm{ft} \text { (brackish). }\end{array}$ \\
\hline-- & 35 & 3,376 & 4,947 & $\begin{array}{l}32,95,180 \\
323\end{array}$ & -- & -- & -- & -- & $\begin{array}{l}\text { Top of bedrock at } 35 \mathrm{ft} \text {, freshwater at } 32,95,180 \text {, and } \\
323 \mathrm{ft} \text {. }\end{array}$ \\
\hline-- & 35 & 3,252 & 4,853 & $\begin{array}{r}26,65,140 \\
436,531\end{array}$ & -- & -- & -- & -- & $\begin{array}{l}\text { Bedrock (shale) at } 35 \mathrm{ft} \text {, freshwater at 26,65, 140, 436, } \\
\text { and } 531 \mathrm{ft} .\end{array}$ \\
\hline-- & 63 & 3,450 & 4,987 & $20,60,520$ & -- & -- & -- & -- & $\begin{array}{l}0-63 \mathrm{ft} \text { gravel, freshwater in gravel at } 20 \text { and } 60 \mathrm{ft} \text { and in } \\
\text { shale at } 520 \mathrm{ft} .\end{array}$ \\
\hline-- & 142 & 3,230 & 4,802 & $82,142,520$ & -- & -- & -- & -- & $\begin{array}{l}0-142 \mathrm{ft} \text { sand and gravel, water } 82-142 \mathrm{ft} \text {, water in shale } \\
\text { at } 520 \mathrm{ft} \text {. }\end{array}$ \\
\hline-- & 30 & 2,687 & 4,338 & $\begin{array}{l}20,50,120 \\
\quad 570\end{array}$ & -- & -- & -- & -- & Shale at $30 \mathrm{ft}$, freshwater at $20,50,120$, and $570 \mathrm{ft}$. \\
\hline-- & 115 & 3,042 & 4,575 & 62,105 & -- & -- & -- & -- & Freshwater 4 inch stream from $62-105 \mathrm{ft}$, shale at $115 \mathrm{ft}$. \\
\hline-- & 4 & 1,740 & 2,986 & 108 & -- & -- & -- & -- & Shale at $4 \mathrm{ft}$, no gas, slight water at $108 \mathrm{ft}$. \\
\hline-- & 10 & 3,270 & 4,803 & 62,173 & -- & -- & -- & -- & $\begin{array}{l}0-10 \mathrm{ft} \text { gravel, freshwater in shale } 1 / 2 \text { inch stream at } 62 \mathrm{ft} \\
\text { and } 1 / 2 \text { stream at } 173 \mathrm{ft} \text {. }\end{array}$ \\
\hline-- & 45 & 2,560 & 4,248 & 140 & -- & -- & -- & -- & $0-45 \mathrm{ft}$ gravel, $1 / 2$ inch stream freshwater at $140 \mathrm{ft}$. \\
\hline-- & 155 & 3,280 & 4,773 & $90,115,145$ & -- & -- & -- & -- & $\begin{array}{l}0-155 \mathrm{ft} \text { gravel, } 3 \text { inch stream at } 90 \mathrm{ft}, 2 \text { inch stream at } \\
115 \mathrm{ft} \text {, and } 3 \text { inch stream at } 145 \mathrm{ft} \text {. }\end{array}$ \\
\hline-- & 10 & 2,920 & 4,628 & 255 & -- & -- & -- & -- & Shale at $10 \mathrm{ft}, 1 / 4$ inch freshwater at $255 \mathrm{ft}$. \\
\hline-- & 35 & 2,690 & 4,350 & 78 & -- & -- & -- & -- & $\begin{array}{l}0-35 \mathrm{ft} \text { gravel, freshwater at } 78 \mathrm{ft} \text { in shale }(1 / 4 \text { inch } \\
\text { stream). }\end{array}$ \\
\hline-- & 120 & 2,705 & 4,439 & $65,120,200$ & -- & -- & -- & -- & $\begin{array}{l}\text { Water from } 65-120 \mathrm{ft}(1 \text { inch stream), shale at } 120 \mathrm{ft} \text {, } \\
\text { water at } 200 \mathrm{ft} 1 / 2 \text { inch stream; directional hole depths } \\
\text { not corrected. }\end{array}$ \\
\hline-- & 10 & 2,484 & 4,147 & 60 & 1,500 & -- & -- & -- & $\begin{array}{l}\text { Shale at } 10 \mathrm{ft}, 1 / 2 \text { inch freshwater at } 60 \mathrm{ft}, 1 / 2 \text { inch } \\
\text { stream brackish at } 1,500 \mathrm{ft} .\end{array}$ \\
\hline-- & 86 & 3,270 & 4,880 & 56 & -- & -- & -- & -- & $0-86 \mathrm{ft}$ gravel and dirt. \\
\hline-- & 60 & 3,286 & 4,090 & 40 & -- & -- & -- & -- & $0-60 \mathrm{ft}$ gravel, 1 inch (fresh) at $40 \mathrm{ft}$ in gravel. \\
\hline-- & 55 & 3,030 & 4,602 & 112 & -- & -- & -- & -- & $0-55 \mathrm{ft}$ gravel, 1 inch freshwater at $112 \mathrm{ft}$. \\
\hline-- & 78 & 3,160 & 4,648 & 62 & -- & -- & -- & -- & Water in gravel at $62 \mathrm{ft}$, shale at $78 \mathrm{ft}$. \\
\hline-- & 100 & 3,040 & 4,158 & 100 & -- & -- & -- & -- & $0-100 \mathrm{ft}$ gravel (water), shale at $100 \mathrm{ft}$. \\
\hline
\end{tabular}


Prepared by the Pembroke Publishing Service Center.

For additional information write to:

New York Water Science Center

U.S. Geological Survey

425 Jordan Road

Troy, NY 12180

Information requests:

(518) 285-5602

or visit our Web site at: http://ny.water.usgs.gov 
